\title{
Requirement of a dopaminergic neuronal phenotype for toxicity of low concentrations of 1-methyl-4-phenylpyridinium to human cells
}

\author{
Stefan Schildknecht* ${ }^{*}$, Dominik Pöltl, Daniel M. Nagel, Florian Matt, Diana Scholz, Julie Lotharius, \\ Nathalie Schmieg, Alberto Salvo-Vargas, Marcel Leist
}

University of Konstanz, Konstanz, Germany

\begin{abstract}
A B S T R A C T
LUHMES cells are conditionally-immortalized non-transformed human fetal cells that can be differentiated to acquire a dopaminergic neuron-like phenotype under appropriate growth conditions. After differentiation by GDNF and cyclic adenosine monophosphate, LUHMES were sensitive to 1-methyl-4-phenylpyridinium $\left(\mathrm{MPP}^{+}\right)$toxicity at $\leq 5 \mu \mathrm{M}$, but resistant to the parental compound 1-methyl-4-phenyl-1,2,3,6-tetrahydropyridine (MPTP). The high homogeneity and purity of the cultures allowed the detection of metabolic changes during the degeneration. Cellular ATP dropped in two phases after 24 and $48 \mathrm{~h}$; cellular glutathione (GSH) decreased continuously, paralleled by an increase in lipid peroxidation. These events were accompanied by a time-dependent degeneration of neurites. Block of the dopamine transporter by GBR 12909 or mazindol completely abrogated $\mathrm{MPP}^{+}$toxicity. Inhibition of de novo dopamine synthesis by $\alpha-$ methyl-L-tyrosine or 3-iodo-L-tyrosine attenuated toxicity, but did not reduce the initial drop in ATP. Inhibition of mixed lineage kinases by CEP1347 completely prevented the MPP ${ }^{+}$-induced loss of viability and intracellular GSH, but failed to attenuate the initial drop of ATP. For the quantitative assessment of neurite degeneration, an automated imaging-based high content screening approach was applied and confirmed the findings made by pharmacological interventions in this study. Our data indicate that inhibition of mitochondrial ATP synthesis is not sufficient to trigger cell death in $\mathrm{MPP}^{+}$-treated LUHMES.
\end{abstract}

\section{Introduction}

Parkinson's disease (PD) is characterized by a relatively selective degeneration of the dopaminergic neurons in the Substantia nigra pars compacta (SNpc), and a concomitant loss of dopamine in their target regions. In some patients the reason for the cell loss can be traced back to a mutation in one of the PARK genes, but the disease trigger has remained unknown in the overwhelming majority of cases (Thomas and Beal, 2007). The progression of PD is invariably accompanied by a series of events including mitochondrial dysfunction, oxidative stress, and an impairment of the protein turnover in dopaminergic neurons as well as an inflammation-like activation of surrounding glial cells (Hald et al., 2007; Litvan et al., 2007a; Litvan et al., 2007b). It has been assumed that the remarkable selectivity of the degeneration for a small group of neurons both in the genetic and idiopathic forms of PD, must be linked to some intrinsic property of the susceptible cells. One of these sensitizing factors may be the susceptibility of dopamine and other catecholamines to undergo rapid autoxidation when they are released from their vesicular storage sites into the cytoplasm, that is associated with the generation of reactive

\footnotetext{
* Corresponding author. University of Konstanz, PO Box M657, D-78457 Konstanz, Germany. Fax: +497531885039.

E-mail address: Stefan.Schildknecht@uni-konstanz.de (S. Schildknecht).
}

metabolites and oxygen radicals (Stokes et al., 1999; Lotharius and Brundin, 2002). This feature would raise the endogenous level of oxidative stress, in particular under conditions of elevated levels of free iron. Neurons in the SNpc of PD patients, which are rich in dopamine and iron, are therefore considered to be particularly sensitive to general forms of damage not necessarily harmful to other neurons (Berg and Hochstrasser, 2006).

The research of PD associated events and their pharmacological modulation by neuroprotective drugs strongly relies on experimental model systems that reproduce the major features of the human disease. A remarkably PD-like disease state is for instance triggered by the small heterocyclic chemical 1-methyl-4-phenyl-1,2,3,6-tetrahydropyridine (MPTP) in mice, primates and man (Langston et al., 1983). In mouse models, the compound is generally administered systemically in bolus doses and leads to dopamine depletion within hours and a selective neurodegeneration within days. In contrast to $\mathrm{PD}$, the degeneration does not further progress after the end of dosing when a stable state of damage has been reached (Jakowec and Petzinger, 2004). In primates, a defined state of degeneration can be obtained by delivery of small doses over weeks to months, but also in these models, the final degeneration does not progress further, once the toxin dosing is discontinued (Meissner et al., 2003). Although the time frames of PD and MPTP poisoning are largely different, a similar final neuropathological and motor behavioural situation is created, 
and there is a possibility that the degeneration in the presence of MPTP shares mechanisms similar to those that can be observed in the progression of PD (Jakowec and Petzinger, 2004). Therefore, the mechanisms of MPTP poisoning have been the subject of intensive research. MPTP can be administered systemically, as its lipophilic structure allows it to freely pass the blood-brain barrier. The compound itself is non-toxic to cells, but it may be converted, e.g. by astrocytic monoamine oxidase $\mathrm{B}$, into $\mathrm{MPDP}^{+}$(1-methyl-4phenyl-2,3-dihydropyridinium) that then undergoes spontaneous oxidation to yield $\mathrm{MPP}^{+}$(1-methyl-4-phenylpyridinium) (Langston et al., 1984; Markey et al., 1984). This metabolite is the real parkinsonian toxin, but it cannot be used systemically, as it does not cross the blood-brain barrier. $\mathrm{MPP}^{+}$, at the low micromolar concentrations found in vivo, is relatively non-toxic to most cells, while it specifically affects dopaminergic neurons. The selectivity is explained by its enrichment in these cells due to uptake via the dopamine transporter (DAT) (Javitch et al., 1985). Once MPP ${ }^{+}$has entered dopaminergic neurons, the mitochondrial membrane potential is the driver for a further enrichment of the compound in these organelles, where it may reach up to millimolar concentrations (Ramsay and Singer, 1986). At such high local levels, $\mathrm{MPP}^{+}$has been shown to lead to an inhibition of complex I of the respiratory chain, and subsequent oxidative stress coupled to ATP-depletion (Ramsay et al., 1991). A second cellular activity affecting $\mathrm{MPP}^{+}$toxicity is the interaction with dopamine storage vesicles, where $\mathrm{MPP}^{+}$can be sequestered, but also release catecholamines from the acid interior of these organelles into the cytosol and extracellular space (Lotharius and O'Malley, 2000).

A useful MPP ${ }^{+}$toxicity model has to reproduce these mechanistic features, and for mechanistic studies and discovery of new pharmacological targets, especially cell culture models with relatively homogeneous cell populations would be desirable. The use of primary dopaminergic neurons is cumbersome and difficult. Many mechanistic studies are not possible at all, due to the low percentage of dopaminergic cells in the primary cultures. Especially the measurement of cellular biochemical changes and live imaging of cellular events have been extremely challenging. Another approach has made use of phaeochromocytoma and neuroblastoma cell lines such as PC-12 and SH-SY5Y. However, such cells often express dopaminergic features and a complex neurite network only weakly. Consequently, toxicity of $\mathrm{MPP}^{+}$is seen in these models only at relatively high and non cell-selective concentrations $(>100-5000 \mu \mathrm{M}$ ) (Zhu et al., 2007; Fountaine et al., 2008). Thus, alternative and complementary models would be of great benefit.

The LUHMES cell line has been shown to display typical biochemical and morphological features of human dopaminergic neurons (Lotharius et al., 2005). The cells yield a homogeneous population and are sensitive to increased levels of endogenous dopamine in combination with elevated free iron. These features triggered us to examine, whether LUHMES cells exposed to $\mathrm{MPP}^{+}$ would be suitable as degeneration model. After initial success with this system, we proceeded to examine whether metabolic changes may be measured in the cells, and whether the degeneration events may be followed in live neurons. In particular, we examined the dependence of $\mathrm{MPP}^{+}$toxicity on the dopaminergic phenotype and finally in how far the system was suitable for larger pharmacological screens.

\section{Materials and methods}

Materials. CEP 1347 (3,9-Bis[(ethylthio)methyl]-K-252a) was obtained by chemical modification of K-252a (Calbiochem, San Diego, CA) according to standard methods (Kaneko et al., 1997). Methamphetamine was obtained from Lipomed (Arleshein, Switzerland), Iloprost was from Schering (Berlin, Germany). MAO-B, MPTP, $\mathrm{MPP}^{+}, \mathrm{FeCl}_{2}$, mazindol, GBR 12909, reserpine, 3-iodo-L- tyrosine, $\alpha$-methyl-L-tyrosine, desferoxamine mesylate (Desferal), minocycline, calcein-AM and tetramethylrhodamineethylester (TMRE) were obtained from Sigma (Steinheim, Germany). $\mathrm{FeCl}_{2}$ was prepared freshly for each experiment in double-distilled water.

Cell culture. LUHMES (Lund Human Mesencephalic neurons) are a subclone of MESC2.10, described in Lotharius et al. (2002), but with robust dopaminergic characteristics (Lotharius et al., 2005). The cells were derived by conditional immortalization of female human embryonic ventral mesencephalic cells and subsequent clonal selection. The cells are freely available upon request. Propagation of undifferentiated LUHMES was performed by using Nunclon ${ }^{\mathrm{TM}}$ (Nunc, Roskilde, Denmark) cell culture flasks precoated with $50 \mathrm{ng} / \mathrm{ml}$ polyL-ornithine (PLO) and $1 \mu \mathrm{g} / \mathrm{ml}$ fibronectin (Sigma, St. Louis, MO) in $\mathrm{H}_{2} \mathrm{O}$ for at least $3 \mathrm{~h}$. The coating solution was then removed, culture flasks were washed with $\mathrm{H}_{2} \mathrm{O}$ and air-dried before cell seeding. For cell detachment, ATV-trypsin $(138 \mathrm{mM} \mathrm{NaCl}, 5.4 \mathrm{mM} \mathrm{KCl}, 6.9 \mathrm{mM}$ $\mathrm{NaHCO}_{3}, 5.6 \mathrm{mM}$ D-glucose, $0.54 \mathrm{mM}$ EDTA, $0.5 \mathrm{~g} / 1$ trypsin from bovine pancreas Type-II-S; Sigma) was used and incubated for $3 \mathrm{~min}$. Cells were collected in Advanced DMEM/F12 medium (Gibco Invitrogen, Karlsruhe, Germany) and centrifuged at $300 \times \mathrm{g}$ for $5 \mathrm{~min}$ at RT. The cell pellet was resuspended in proliferation medium, consisting of Advanced DMEM/F12, 1× N2 supplement (Invitrogen), $2 \mathrm{mM}$ L-glutamine (Gibco), and $40 \mathrm{ng} / \mathrm{ml}$ recombinant bFGF (R+D Systems, Minneapolis, MN). Cells were grown to a density of $40-50 \%$, the differentiation process was then initiated in cell culture flasks by adding differentiation medium consisting of Advanced DMEM/F12, $1 \times \mathrm{N} 2$ supplement, $2 \mathrm{mM}$ L-glutamine, $1 \mathrm{mM}$ dbcAMP (Sigma), $1 \mu \mathrm{g} / \mathrm{ml}$ tetracycline (Sigma), and $2 \mathrm{ng} / \mathrm{ml}$ recombinant human GDNF ( $R+D$ Systems). After 2 days in culture flasks, cells were trypsinized as described, counted and seeded at a density of 160,000 cells $/ \mathrm{cm}^{2}$ if not otherwise indicated in 24-well Nunclon $^{\mathrm{TM}}$ PLO/fibronectin-coated culture plates in differentiation medium for additional 3 days.

Isolation of primary rat glial cells. Primary cultures were prepared from cerebral cortices of newborn (1 day old) rats (Wistar). Animal breeding and handling was performed by staff of the animal housing unit, University of Konstanz, according to international guidelines. Brains were removed and cleared of the meninges, cortices were mechanically homogenized by pipetting the tissue up and down and finally filtered through a nylon sieve ( $70 \mu \mathrm{m}$; BD Falcon, Bedford, MA). Cells were maintained in DMEM containing 10\% heat inactivated fetal calf serum and $2 \mathrm{mM}$ glutamine (all Biochrom, Berlin, Germany). Glial cells were grown to confluency and then maintained for 1 week before the experiments were performed.

Transfer experiments. Following the 1-week maintenance of glial cells in DMEM, medium was exchanged to LUHMES-differentiation medium, $24 \mathrm{~h}$ prior to experiments. MPTP was then added for 2 days. As control, the MAO-B inhibitor R-(-)-deprenyl hydrochloride (selegiline) was co-incubated. Then, $50 \%$ of the medium of differentiated (4 days) LUHMES cells in 24-well plates was removed and replaced by the glial supernatant. Toxicity was determinated after further incubation for 3 days. The MPTP concentrations indicated in the results refer to the final theoretical concentration on LUHMES cells as if no metabolism had happened. Some of the LUHMES wells that received glial/MPTP medium were treated with the DAT blocker GBR 12909 (100 nM). Alternatively, purified MAO-B (10 U/ml, Sigma) was incubated with $100 \mu \mathrm{M}$ or $500 \mu \mathrm{M}$ MPTP for $24 \mathrm{~h}$. Afterwards, $5 \%$ of the medium of LUHMES cultures was replaced by this solution, and toxicity was determined 3 days later.

\section{Cell viability}

Resazurin metabolization assay (Gartlon et al., 2006). Resazurin (Sigma) was added to the cell culture medium in a final concentration 
of $2.5 \mu \mathrm{g} / \mathrm{ml}$ and measured in $30 \mathrm{~min}$ intervals ( $530 \mathrm{~nm}_{\mathrm{ex}} ; 590 \mathrm{~nm}_{\mathrm{em}}$ ) over a period of $3 \mathrm{~h}$.

MTT reduction assay. $\quad$ MTT (3-(4,5-dimethyl-2-thiazolyl)-2,5diphenyl-2H-tetrazolium bromide) (Sigma) was added directly to the cell culture medium in a final concentration of $0.5 \mathrm{mg} / \mathrm{ml}$ and incubated for $1 \mathrm{~h}$. Medium was then removed, cells were gently washed with PBS, and lysed in 95\% isopropanol/5\% formic acid under vigorous shaking for $20 \mathrm{~min}$. Following a brief centrifugation step to remove cell debris, an aliquot was transferred to a 96-well plate, absorbance was detected at $570 \mathrm{~nm}$ (background at $690 \mathrm{~nm}$ ).

Lactate dehydrogenase $(\mathrm{LDH})$ release assay. $\mathrm{LDH}$ activity was detected separately in the supernatant and cell homogenate. LDH release was expressed in percent as $\mathrm{LDH}$ supernatant/LDH total. Cells were lysed in PBS/0.5\% Triton X-100 for 20 min. $10 \mu \mathrm{l}$ of sample was added to $200 \mu \mathrm{l}$ of reaction buffer containing NADH $(100 \mu \mathrm{M})$ and sodium pyruvate $(600 \mu \mathrm{M})$ in sodium phosphate buffer adjusted to $\mathrm{pH}$ 7.4 by $40.24 \mathrm{mM} \mathrm{K}_{2} \mathrm{HPO}_{4}$ and $9.7 \mathrm{mM} \mathrm{KH}_{2} \mathrm{PO}_{4}$ buffer. Absorption at $340 \mathrm{~nm}$ was detected at $37{ }^{\circ} \mathrm{C}$ in 1 min intervals over a period of 20 min.

ATP assay. Cells grown in 24-well plates were lysed in PBS-buffer containing $0.5 \%$ phosphatase-inhibitor cocktail 2 (Sigma) and boiled at $95^{\circ} \mathrm{C}$ for $10 \mathrm{~min}$. Following centrifugation at $10,000 \times \mathrm{g}$ for $5 \mathrm{~min}$ for the removal of cell debris, protein content in the supernatant was detected and adjusted to equal amounts, samples were then diluted $1: 10$ in PBS $/ 0.5 \%$ phosphatase-inhibitor buffer. For the detection of ATP levels, a commercially available ATP assay reaction mixture (Sigma), containing luciferin and luciferase, was used. $50 \mu \mathrm{l}$ of adjusted sample and $100 \mu \mathrm{l}$ of assay mix were added to a white half-area 96-well plate. Standards were prepared by serial dilutions of ATP disodium salt hydrate (Sigma) to obtain concentrations ranging from $1000 \mathrm{nM}$ to $7.8 \mathrm{nM}$.

Glutathione determination. Cells were washed twice with PBS and lysed in $200 \mu \mathrm{l}$ of $1 \%$ sulfosalicylic acid (w/v) on ice. The lysates were collected, sonicated 3-4 times on ice and centrifuged at 12,000 $\times \mathrm{g}$ for $5 \mathrm{~min}$ at $4{ }^{\circ} \mathrm{C}$ to remove cell debris. Total glutathione content (GSH + GSSG) was determined by a DTNB (5,5'-Dithiobis(2nitrobenzoic acid)) reduction assay. Supernatants were diluted 1:10 in $\mathrm{H}_{2} \mathrm{O}, 100 \mu \mathrm{l}$ sample was mixed with $100 \mu$ assay mixture containing $300 \mu \mathrm{M}$ DTNB, $1 \mathrm{U} / \mathrm{ml}$ glutathione-reductase, $400 \mu \mathrm{M}$ NADPH, $1 \mathrm{mM}$ EDTA in 100 mM sodium phosphate buffer, pH 7.5 (all Sigma). DTNB reduction was measured photometrically at $405 \mathrm{~nm}$ in 5 min intervals over $30 \mathrm{~min}$. Total protein content of each sample was detected after neutralization of the precipitated protein pellet with $100 \mathrm{mM} \mathrm{NaOH}$ by BCA reagent (Pierce, Thermo Scientific, Rockford, IL). Oxidized glutathione (GSSG) was detected by scavenging GSH with 2vinylpyridine for $1 \mathrm{~h}$ and revealed intracellular levels between 1 and 5\% of total glutathione content in controls. GSH and GSSG standard curves (Sigma) were performed by serial dilutions ranging from $1000 \mathrm{nM}$ to $7.8 \mathrm{nM}$, respectively.

Malondialdehyde assay. Following collection of cells in PBS, sonication on ice, and adjustment to equal protein content, $100 \mu \mathrm{l}$ sample was mixed with $200 \mu \mathrm{l}$ of assay mix containing $15 \%$ trichloroacetic acid, $0.375 \%$ thiobarbituric acid in $250 \mathrm{mM} \mathrm{HCl}$. After thorough vortexing, samples were boiled at $95{ }^{\circ} \mathrm{C}$ for $15 \mathrm{~min}$ and centrifuged at $1000 \times \mathrm{g}$ for $10 \mathrm{~min}$. Absorbance of supernatant was detected at $535 \mathrm{~nm}$ and was converted to equivalents of MDA using an absorbance coefficient of $1.56 * 10^{5} / \mathrm{M}^{-1} \mathrm{~cm}^{-1}$.

Western-blot analysis. Cells were lysed in RIPA-buffer (50 mM Trisbase, $150 \mathrm{mM} \mathrm{NaCl}, 1 \mathrm{mM}$ EDTA, $0.25 \%$ sodium deoxycholate, $1 \%$ $\mathrm{NP} 40,1 \mathrm{mM} \mathrm{Na}_{3} \mathrm{VO}_{4}, 50 \mathrm{mM} \mathrm{NaF}, \mathrm{pH} 7.5$ ). Protein determination was performed by using a BCA protein assay kit (Pierce). Twenty-five micrograms of total protein was loaded onto 8\% SDS gels. Proteins were transferred onto nitrocellulose membranes (Amersham, Buckinghamshire, UK), loading and transfer were controlled by brief Ponceau staining, washed membranes were then blocked with $5 \%$ milk in PBS-Tween $(0.1 \%)$ for $2 \mathrm{~h}$. Primary antibodies were incubated at $4{ }^{\circ} \mathrm{C}$ over night. Following washing steps with PBS-Tween, horseradish peroxidase-conjugated secondary antibodies were incubated for $1 \mathrm{~h}$ at RT, for visualization ECL Western blotting substrate (Pierce) was used. Anti-TH antibody was obtained from Chemicon/ Millipore (mouse, 1:5000), anti $\alpha$-synuclein antibody (ASY-5) was a kind gift from Dr. P.H. Jensen (rabbit, 1:2500), anti GAPDH antibody was from Sigma (mouse, 1:5000). As secondary antibodies, antimouse HRP (1:5000, Jackson Immuno Research) and anti-rabbit HRP (1:5000, GE Healthcare) were used.

Immunocytochemistry. Cells were grown on glass cover slips (Menzel, Braunschweig, Germany) (10 mm $\varnothing$; \#1) in 24-well plastic cell culture plates (Nunclon ${ }^{\mathrm{TM}}$ ). Following treatment, cells were fixed with $4 \%$ paraformaldehyde for $20 \mathrm{~min}$ at $37{ }^{\circ} \mathrm{C}$ and washed with PBS. Blocking was performed by applying $1 \%$ BSA (Calbiochem, San Diego, CA) for $1 \mathrm{~h}$, primary antibodies in PBS-Tween $(0.1 \%)$ were incubated for $2 \mathrm{~h}$ at RT, or at $4{ }^{\circ} \mathrm{C}$ over night, secondary antibodies were incubated for $45 \mathrm{~min}$ at RT. For visualization, a Olympus IX 81 microscope (Hamburg, Germany) equipped with a F-view CCD camera was used. Hoechst $(1 \mu \mathrm{g} / \mathrm{ml})$ was added for 15 min prior to the final washing step. For image processing, Cell $\mathrm{P}$ software (Olympus) was used. The antibody against neuronal class $\beta$-III tubulin (TUJ1) was from Convance (mouse, 1:1000). As secondary antibody, anti-mouse IgG, Alexa 488 (1:1000) (Molecular Probes) was used.

Image analysis of neurite degeneration. For a quantitative assessment of neurite degeneration in response to $\mathrm{MPP}^{+}$treatment, cells were seeded in 96-well Nuclon plates at a density of 120,000 cells/ $\mathrm{cm}^{2}$ (40,000 cells/well), and analysed by epifluorescence imaging using an automated, microplate-reading microscope (Array-Scan II ${ }^{\circledR}$ HCS Reader, Cellomics, Pittsburgh, PA) equipped with a Hamamatsu ORCA-ER camera (resolution $1024 \times 1024$; run at $2 \times 2$ binning). 30 min prior to the imaging scan, cells were loaded with $1 \mu \mathrm{g} / \mathrm{ml}$ Hoechst dye $\mathrm{H}-33342,50 \mathrm{nM}$ tetramethylrhodamineethylester (TMRE) and $1 \mu \mathrm{M}$ calcein-AM. Images were collected in three different fluorescent channels using the $20 \times$ objective, and excitation/emission wavelengths of: $365 \pm 50 / 525 \pm 15 \mathrm{~nm}$ for $\mathrm{H}-33342$ on channel $1575 \pm 25 / 640 \pm 35 \mathrm{~nm}$ for TMRE on channel 2 , and $475 \pm$ $40 / 525 \pm 15 \mathrm{~nm}$ for calcein on channel 3. In all three channels a fixed exposure time and an intensity histogram-derived threshold for object identification was used. Intensity histogram-derived thresholds were calculated separately for each image, based on the distance of the intensity peaks of background pixels and signal (=neurite) pixels in the histogram. For each well, ten fields of $330 \times 330 \mu \mathrm{m}$ size were scanned and the image sets were analysed using the Spot Detector Bioapplication V2. In brief, this is based on an image analysis algorithm which identifies nuclei as objects in channel 1 according to their intensity, size, area and shape. A "virtual cell soma area = VCSA" was defined around each nucleus based on the identified nuclear area, expanded by $8 \mu \mathrm{m}$ into all directions. A "virtual cellular area $=$ VCA" was defined by a segmentation routine based on virtually inflating all nuclei in a homogeneous way until their boundaries touched everywhere. Structure identification in channel 2 was solely performed in the "virtual neurite area (VNA)" $(\mathrm{VNA}=\mathrm{VCA}-\mathrm{VCSA})$. The major discriminator of the spot detection algorithm was "pixel signal intensity" in relation to the close local environment. All neurite-positive pixels over all VNA were summed up and denominated "neurite mass". "Neurite mitochondrial mass" was determined in a similar way to neurite mass based on channel 3 signals. 
Measurement of dopamine (DA) content. For determination of endogenous intracellular DA, cells were differentiated for various time intervals in 24-well plates, lysed in $100 \mu \mathrm{l} 0.1 \mathrm{M}$ perchloric acid/ $100 \mu \mathrm{M}$ ascorbic acid and subjected to one cycle of freeze-thawing. A small aliquot was used for determination of the protein content by BCA $^{\mathrm{TM}}$ Protein Assay Kit (Thermo Scientific, Rockford, IL). Samples were adjusted to equal protein contents and cell debris removed by brief centrifugation at $15,000 \times g$. The supernatant was used for DA detection by a commercially available enzyme-linked immunoassay (IBL, Hamburg, Germany), according to the manufacturer's instructions. For an assessment of the unspecific background signal, homogenates of undifferentiated LUHMES (day 0; collected $12 \mathrm{~h}$ after seeding) were compared to rat primary glial cells or an equivalent protein amount in form of albumin. All resulted in the same low basic signal. For determination of DA uptake, cells in 96-well plates were washed $1 \times$ with warm Hanks Balanced Salt Solution (HBSS) to remove medium, and incubated with $4625 \mathrm{~Bq} /$ well $\left[{ }^{3} \mathrm{H}\right]-\mathrm{DA}$ $(=29 \mathrm{nM})(1.41 \mathrm{TBq} / \mathrm{mmol}$ stock solution; Perkin Elmer, Boston, $\mathrm{MA}), 10 \mu \mathrm{M}\left[{ }^{1} \mathrm{H}\right]-\mathrm{DA}$ and $100 \mu \mathrm{M}$ ascorbic acid for time periods ranging from 10 to $120 \mathrm{~min}$. To assess the DAT-selectivity of the uptake, a parallel experiment with GBR $12909(0.1 \mu \mathrm{M})$ pre-treated (30 min) cells was performed and the difference in values was calculated.

$\left.{ }^{3} \mathrm{H}\right]-\mathrm{MPP}^{+}$uptake assay. Cells $(40,000 /$ well) grown in 96-well plates were washed $1 \times$ with Hank's Balanced Salt Solution (HBSS), containing $\mathrm{Ca}^{2+}$, $\mathrm{pH}$ 7.4. LUHMES were treated with the DAT blockers GBR $12909(0.1 \mu \mathrm{M})$ or mazindol $(100 \mu \mathrm{M}) 30$ min before $\mathrm{MPP}^{+}$was added. Then $4625 \mathrm{~Bq} /$ well $(=15 \mathrm{nM}){ }^{3} \mathrm{H}^{-}-\mathrm{MPP}^{+}(3.1635 \mathrm{TBq} / \mathrm{mmol}$ stock solution; Perkin Elmer, Boston MA) and $5 \mu \mathrm{M}\left[{ }^{1} \mathrm{H}\right]-\mathrm{MPP}^{+}$was added. The supernatants were collected after $30 \mathrm{~min}$ (or times as indicated), cells were washed $5 \times$ gently with warm HBSS and then lysed with PBS/0.1\% Triton X-100. Radioactivity in cell lysates and the respective supernatants was measured using a Beckman LS-6500 scintillation counter.

Statistics. Values are expressed as the mean $\pm \operatorname{SD}(n \geq 3)$. Data were analyzed by one-way ANOVA or Student's t-test as appropriate, differences between treatments were determined by post-hoc Bonferroni's or Dunnet's test (Prism software). Means were considered statistically significant at $p<0.05$.

\section{Results}

\section{Characterization of the model system}

The human dopaminergic cell line LUHMES, a clone of MESC2.10, has been described and further characterized earlier (Lotharius et al., 2002; Lotharius et al., 2005). The cells can be differentiated to postmitotic neuron-like cells, when the v-myc transgene is switched off by tetracycline. Under these in vitro conditions, the cells stably express the dopamine transporter (DAT), the vesicular monoamine transporter (VMAT-2), tyrosine hydroxylase (TH), the neuronal form of $\beta$ III tubulin, and increased levels of $\alpha$-synuclein (Lotharius et al., 2002; Paul et al., 2007, and this study). The cells have been shown to be sensitive to methamphetamine (METH)-driven neurite degeneration in the presence of free iron $\left(\mathrm{Fe}^{2+}\right)$. The toxicity of METH depended strictly on the presence of endogenous dopamine (Lotharius et al. 2005).

For the present study, we slightly modified the differentiation system, by addition of tetracycline already $48 \mathrm{~h}$ before the cells were re-plated for the final experiments. This procedure, allowed a very exact titration of cell numbers, as the plated cells did not proliferate further. Neuronal differentiation and sensitivity to $\mathrm{METH} / \mathrm{Fe}^{2+}$ (see below) were not affected by this change of protocol. All toxicity experiments were initiated on day 5 after tetracycline addition (i.e. day 3 after re-plating), when TH was strongly expressed, $\alpha$-synuclein was upregulated (Fig. 1A), and the cells displayed the full neuronal morphology including expression of $\beta$-III tubulin along all neurites

A

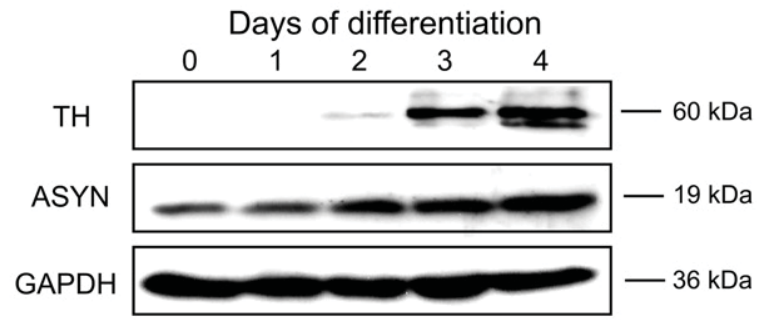

B

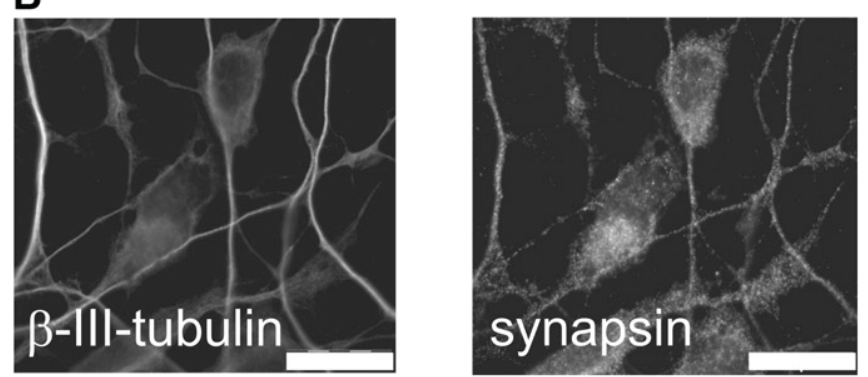

C

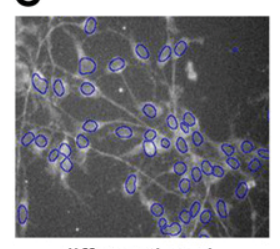

differentiated $(\mathrm{TH}+\mathrm{H}-33342)$

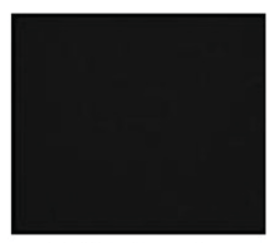

undifferentiated

(TH)

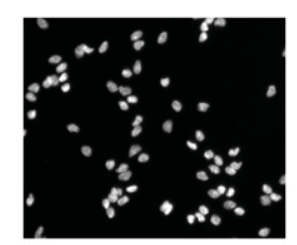

undifferentiated (H-33342)
D

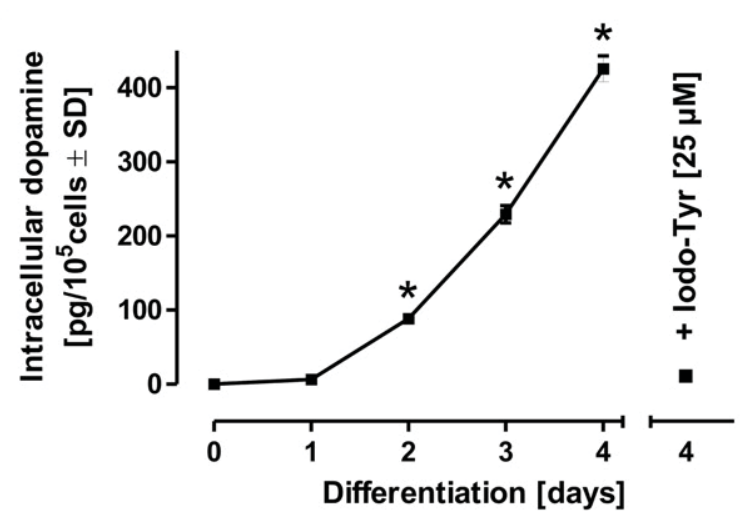

Fig. 1. Acquisition of dopaminergic neuronal-like phenotype by LUHMES cells. (A) LUHMES cells were seeded in 24 well plates after $48 \mathrm{~h}$ pre-differentiation in growth medium containing tetracycline. After 0-4 days in differentiation medium, cells were harvested and proteins analyzed by Western blot. Expression of tyrosine hydroxylase $(\mathrm{TH})$ was under the detection limit at the beginning of the differentiation. Alphasynuclein (ASYN) was strongly increased relative to the loading control glyeraldehyde3-phosphate dehydrogenase (GAPDH). (B) LUHMES were plated on glass cover slips, fixed after 4 days of differentiation and stained for $\beta$-III tubulin and synapsin. Images of the two antigens from the same field clearly indicate synapsin-positive structures in the neurites in addition to the somata. Scale bar: $20 \mu \mathrm{m}$. (C) LUHMES grown in 96-well plates and differentiated for 4 days (left) or left undifferentiated (middle and right, cells from the same field) were stained for TH and chromatin (H-33342). Undifferentiated cells showed no TH stain at all. The image to the left shows a representative image of the $\mathrm{TH}$ stain (TH intensity in grey values on black background). The circles mark the nuclear area as identified automatically by the software on basis of H-33342 staining of the same field. TH intensity in these areas was recorded automatically in 500 cells per condition. Image width $=175 \mu \mathrm{m}$. (D) Cells were differentiated for the time periods indicated in 24-well plates and lysed for the detection of intracellular dopamine. As control, the TH inhibitor iodo-tyrosine was added for the entire differentiation period. Data are expressed as means \pm SD of quadruplicate samples. 
and punctate synapsin staining similar to primary neurons (Fig. 1B). To investigate the percentage of TH-positive cells, LUHMES grown in 96-well plates were immunostained and analysed by an automated microscope system that quantified $\mathrm{TH}$ staining intensity in the perinuclear area (as identified by the chromatin dye H-33342). Almost $100 \%$ of the identified cell somata were stained positive for $\mathrm{TH}$, and also the corresponding neurites were positive (Fig. 1C). This phenotype was robustly observed, also when e.g. cell densities varied between 15,000 cells/well and 70,000 cells/well. The TH content was linked to the dopaminergic phenotype as determined by measurements of cellular dopamine content. While the neurotransmitter was absent in undifferentiated cells, its concentration steadily increased during differentiation, and this increase was blunted by co-incubation with the TH inhibitor iodo-tyrosine (Fig. 1D). Differentiated cells were also able to accumulate radioactive dopamine by a mechanism sensitive to DAT inhibition in the presence of excess unlabelled dopamine (not shown).

\section{Pronounced $\mathrm{MPP}^{+}$toxicity at micromolar concentrations}

Many experiments with primary neurons have shown that specific toxicity of $\mathrm{MPP}^{+}$is observed at concentrations clearly below $20 \mu \mathrm{M}$ (Carrasco and Werner, 2002), while higher concentrations can lead to unspecific killing of non-dopaminergic cells in ventral mesencephalic cultures, or completely unrelated cell types like cerebellar granule cells (Leist et al., 1998; Volbracht et al., 2006) or even hepatocytes (Di Monte et al., 1987; Wu et al., 1990). To test the suitability of our model system to replace primary neuron cultures, differentiated LUHMES cells were exposed to $\mathrm{MPP}^{+}$in the range of $1-25 \mu \mathrm{M}$ for $72 \mathrm{~h}$. Standard metabolic activity assays, such as MTT or resazurin reduction, indicated a steep drop of viability at $\mathrm{MPP}^{+}$concentrations between 1 and $5 \mu \mathrm{M}$. As MPP ${ }^{+}$may interfere with the function of these assays, cell death was directly determined by quantification of the percentage of lactate dehydrogenase (LDH) released from the cells, that correlated well with MTT or resazurin results (Fig. 2A). The homogeneous culture system also allowed to investigate levels of ATP and GSH in cells exposed to MPP ${ }^{+}$. ATP levels dropped steeply at $\mathrm{MPP}^{+}$concentrations $>1 \mu \mathrm{M}$, and $5 \mu \mathrm{M} \mathrm{MPP}{ }^{+}$resulted in a reduction by approximately $80 \%$, even when ATP was standardized to remaining cellular protein (Fig. 2B). GSH dropped to about $50 \%$ at $5 \mu \mathrm{M} \mathrm{MPP}^{+}$. From these data, it appears that the drop of ATP is more steep and pronounced in this model, than the drop in GSH (Fig. 2B). Viability analysis at the single cell level, using calcein-AM staining, showed that about $60-70 \%$ of the individual cells died at an $\mathrm{MPP}^{+}$concentration of $5 \mu \mathrm{M}$ after $72 \mathrm{~h}$ (Fig. 2C). This corroborated our findings from the population viability measures (e.g. LDH or MTT), and showed that the model was in a similar sensitivity range with respect to $\mathrm{MPP}^{+}$ concentrations as primary rodent dopaminergic neurons. The $\mathrm{MPP}^{+}$ concentration of $5 \mu \mathrm{M}$ was chosen for further experiments.

\section{Time course of metabolic changes during $\mathrm{MPP}^{+}$toxicity}

Differentiated LUHMES cells were exposed to $\mathrm{MPP}^{+}(5 \mu \mathrm{M})$ in a time-dependent manner. Parallel cultures were alternatively treated with the established combination of $\mathrm{METH} / \mathrm{Fe}^{2+}(1 \mathrm{mM} / 75 \mu \mathrm{M})$ for direct comparison (Lotharius et al., 2005). Both systems revealed an almost identical loss of cell viability over time as measured by MTT reduction (Fig. 3A), resazurin assay or calcein-AM staining (not shown). Interestingly, intracellular ATP remained relatively constant for $24 \mathrm{~h}$ after exposure to $\mathrm{MPP}^{+}$, and then declined steeply to $<30 \%$ at $36 \mathrm{~h}$ (Fig. 3B). This lag phase may indicate the necessity for threshold intracellular/intramitochondrial levels of $\mathrm{MPP}^{+}$, required for an efficient inhibition of complex I and therefore ATP synthesis. At extended periods of incubation $\left(>50 \mathrm{~h}\right.$ ), also METH $/ \mathrm{Fe}^{2+}$ lead to an almost complete loss of cellular ATP, although these toxicants do not directly inhibit glycolysis or the respiratory chain. This ATP loss is
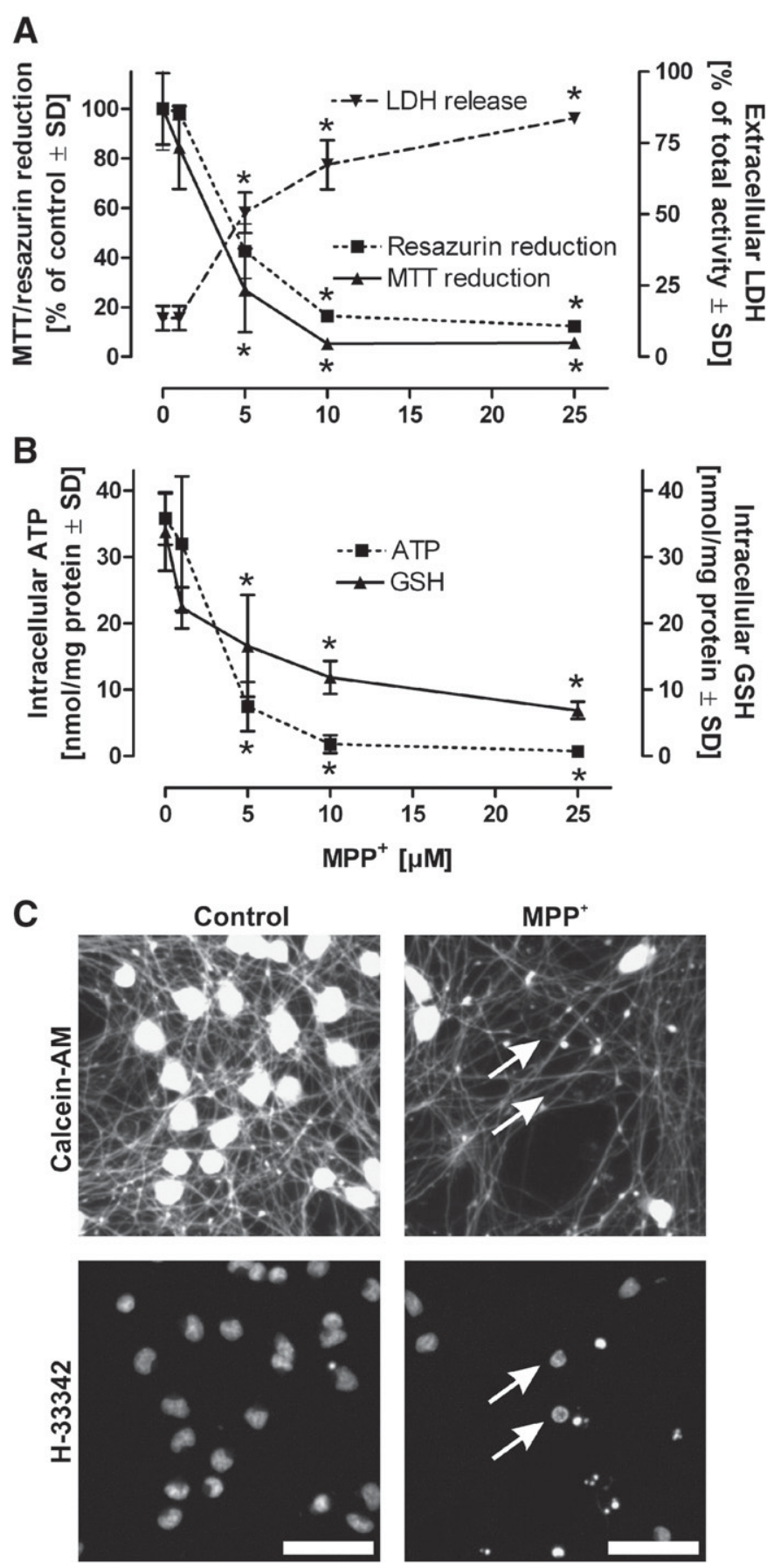

Fig. 2. Concentration-dependence of $\mathrm{MPP}^{+}$toxicity. Cultures of fully differentiated LUHMES cells that had been seeded at a density of 160,000 cells $/ \mathrm{cm}^{2}(=300,000$ cells/ well of a 24-well plate) were exposed to various concentrations of $\mathrm{MPP}^{+}$for 3 days. (A) Cell viability was assessed by the MTT or resazurin reduction assays, respectively, as well as by the LDH-release assay. (B) Changes of the major cellular metabolites ATP and glutathione (GSH) were measured in parallel cultures and standardized to the cellular protein content. All data are expressed as means $\pm S D$ of quadruplicate samples. (C) Cells treated with solvent (control) or $\mathrm{MPP}^{+}$were stained live with $\mathrm{H}-33342$ to visualize the nuclei and with calcein-AM to visualize cellular structures enclosed by an intact plasma membrane. Somata and neurites are visible as viable structures in control cultures for each nucleus marked by $\mathrm{H}-33342$. In $\mathrm{MPP}^{+}$-treated cultures several cells identified by their nuclei (see arrows for examples) are calcein-negative (arrows indicate nuclear position). Scale bar: $160 \mu \mathrm{m}$.

most likely secondary to oxidative destruction of vital cellular structures (e.g. mitochondria) or a highly increased energy demand under conditions of oxidative stress and increased membrane permeability. These processes may also be involved in the ATP drop 
A
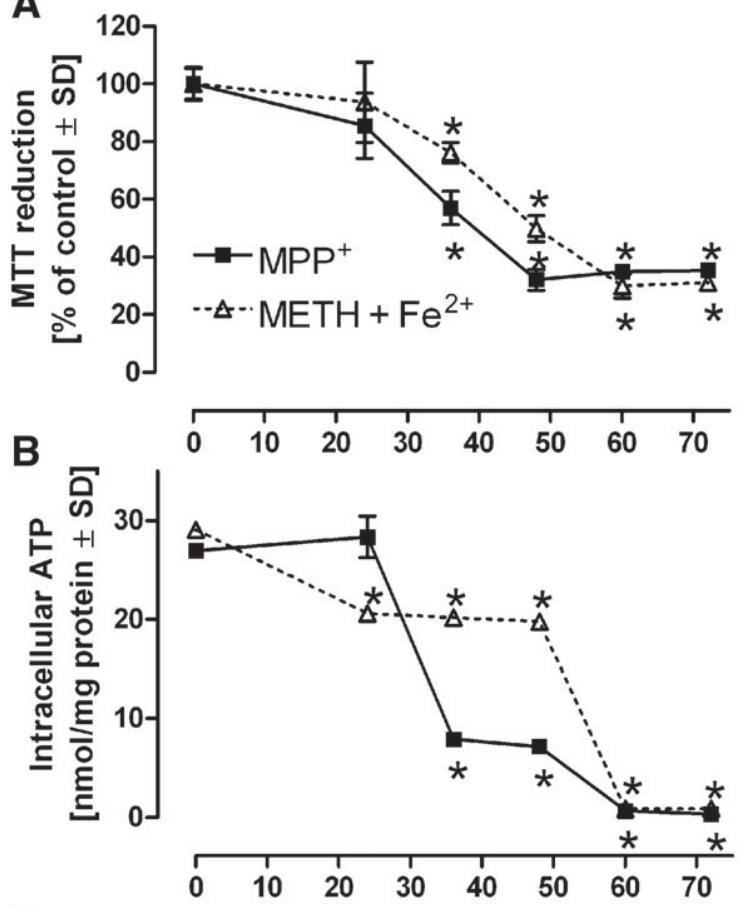

C
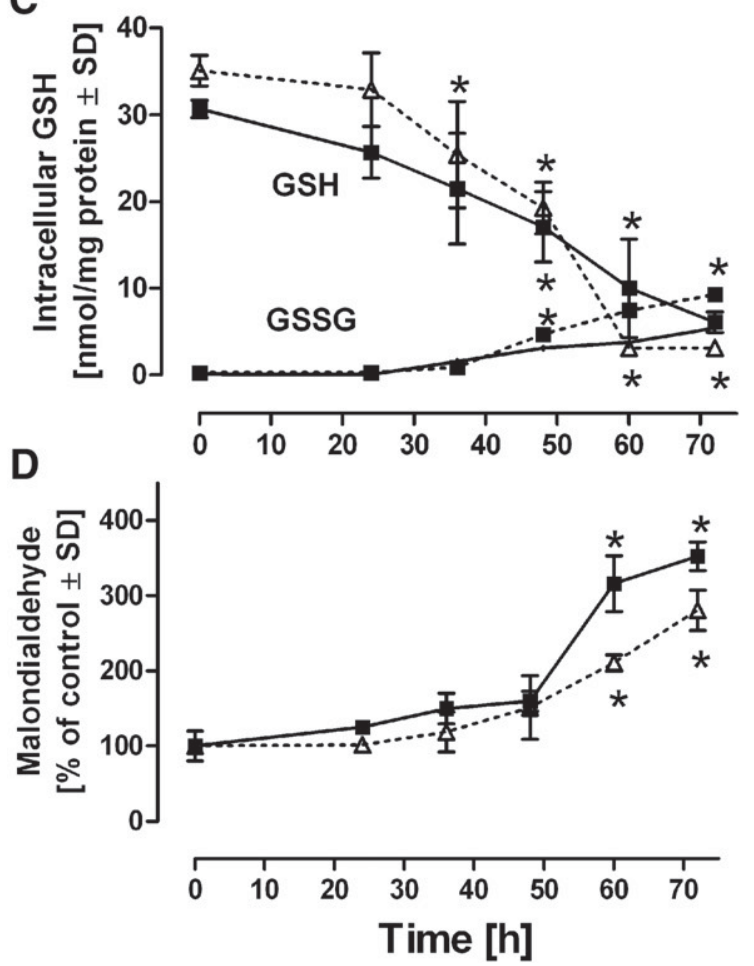

Fig. 3. Time course of $\mathrm{MPP}^{+}$and $\mathrm{METH} / \mathrm{Fe}^{2+}$ toxicity. Fully differentiated LUHMES cells were exposed either to $\mathrm{MPP}^{+}(5 \mu \mathrm{M})$ or to methamphetamine (METH) $(1 \mathrm{mM})$ in combination with $\mathrm{Fe}^{2+}(75 \mu \mathrm{M})$ for various time periods. For both conditions (A) cell viability, as indicated by MTT reduction, (B) intracellular levels of ATP or (C) GSH and GSSG (= oxidized GSH) as well as (D) malondialdehyde (marker for lipid peroxidation) were measured. All data are expressed as means \pm SD of quadruplicate samples.

observed in the $\mathrm{MPP}^{+}$model (Fig. 3B). A gradual decline of cellular GSH levels was observed in both experimental models indicating an increasing disability of the cells to maintain the redox potential and antioxidant defense systems (Fig. 3C). The loss of reduced GSH was accompanied by an increase in intracellular oxidized GSSG. One of the downstream consequences of an exhausted GSH system, is uncon- trolled oxidative events like lipid peroxidation in cellular membranes. Malondialdehyde (MDA) formation is a marker for such events, and indeed was observed in both the $\mathrm{MPP}^{+}$and the $\mathrm{METH} / \mathrm{Fe}^{2+}$ models after $60-72 \mathrm{~h}$ of incubation. MDA formation coincided with the pronounced loss of intracellular ATP and GSH levels at these late stages (Fig. 3D).

\section{Specificity of $\mathrm{MPP}^{+}$toxicity to differentiated neurons}

Experimental animals can tolerate very high doses of MPTP, when its conversion to $\mathrm{MPP}^{+}$is blocked, e.g. by deprenyl or MAO-B knockout (Heikkila et al., 1984; Grimsby et al., 1997). A bona fide cell culture model has to reproduce this feature. Therefore, LUHMES cells were exposed to MPTP concentrations up to $100 \mu \mathrm{M}$ that had no significant impact on viability (not shown). Thus, LUHMES do not seem to be capable of converting MPTP to $\mathrm{MPP}^{+}$, and only react selectively to the active metabolite - similar to primary dopaminergic neurons. Another major specificity feature known from in vivo models and primary cultures is the dopaminergic phenotype. Its role was assessed by a direct comparison of undifferentiated (non-dopaminergic) to neuronally differentiated LUHMES. Undifferentiated cells were completely resistant to $5 \mu \mathrm{M} \mathrm{MPP}{ }^{+}$, and only a slight decline of viability ( $<20 \%$ ) was seen at concentrations up to $100 \mu \mathrm{M}$ (Fig. $4 \mathrm{~A}$ ). Thus, LUHMES cells specifically "gain" $\mathrm{MPP}^{+}$-sensitivity upon dopaminergic differentiation.

In order to further characterize the uptake of $\mathrm{MPP}^{+}$, we used $\left[{ }^{3} \mathrm{H}\right]-$ labelled compound. A time-course analysis revealed that maximal uptake was achieved after roughly $60 \mathrm{~min}$ (not shown). To examine the DAT-dependence of $\mathrm{MPP}^{+}$uptake, cells were exposed to $\left[{ }^{3} \mathrm{H}\right]-$ $\mathrm{MPP}^{+}$for $30 \mathrm{~min}$ in the presence or absence of the DAT inhibitors GBR $12909(0.1 \mu \mathrm{M})$ or mazindol $(100 \mu \mathrm{M})$, or in the presence of a 10 -fold excess of unlabelled $\left[{ }^{1} \mathrm{H}\right]-\mathrm{MPP}^{+}$. Both DAT blockers and excess of $\left[{ }^{1} \mathrm{H}\right]-\mathrm{MPP}^{+}$efficiently reduced the uptake of $\left[{ }^{3} \mathrm{H}\right]-\mathrm{MPP}^{+}$. Thus, $\mathrm{MPP}^{+}$ uptake in the LUHMES model was strictly DAT-dependent (Fig. 4B).

In the next set of experiments, we examined the conditions necessary to observe MPTP toxicity to LUHMES cells - in analogy to animal experimental data. In a first pilot experiment MPTP was incubated with MAO-B, and the reaction mixture then added to LUHMES cells. Under these conditions $25 \mu \mathrm{M}$ MPTP resulted in a viability reduction of $50-60 \%$, which was entirely blocked by incubation of the enzyme with R-deprenyl (data not shown). In a next step we used a sequential incubation system, in which MPTP was first incubated with primary rat glial cells, and then transferred to LUHMES cells. A concentration of $50 \mu \mathrm{M}$ MPTP triggered significant, and MAO-B dependent toxicity of LUHMES cells (Fig. 4C). In a further experiment, we examined the MPTP toxicity of this sequential coculture in more detail. MPTP concentrations as low as $2.5 \mu \mathrm{M}$ were sufficient to trigger LUHMES toxicity as measured in the resazurin assay (Fig. 4D) or LDH-assay (not shown). Toxicity was blocked when glial cells, but not LUHMES were incubated with R-deprenyl, and toxicity was also blocked, when only LUHMES cells were co-incubated with a DAT inhibitor (Fig. 4D). These data indicate, that conversion of MPTP by glial MAO-B and uptake of the reaction product via DAT is necessary for MPTP toxicity to LUHMES cells.

\section{Requirement of a functional DAT for manifestation of $\mathrm{MPP}^{+}$toxicity}

To investigate whether the dopamine transporter function is linked to the sensitivity of differentiated LUHMES cells to $\mathrm{MPP}^{+}$, the impact of DAT inhibition on different toxicity and stress parameters was examined. Co-incubation of cells with toxicant plus the DAT inhibitors mazindol (Fig. 5A) or GBR 12909 (Fig. 5B) led to a concentrationdependent reduction of $\mathrm{MPP}^{+}$toxicity by both compounds. A full and permanent inhibition of the DAT (by high concentrations of GBR 12909) restored cells biochemically and morphologically (Fig. 5C) to the levels of untreated control cells. 
The role of cellular dopamine synthesis for $\mathrm{MPP}^{+}$toxicity

To assess the role of de novo synthesis of dopamine in the MPP ${ }^{+}$ model, the tyrosine hydroxylase (TH)-inhibitors $\alpha$-methyl-L-tyrosine and 3-iodo-L-tyrosine were incubated with differentiated LUHMES cells together with $\mathrm{MPP}^{+}(5 \mu \mathrm{M})$. Both TH inhibitors attenuated the

A

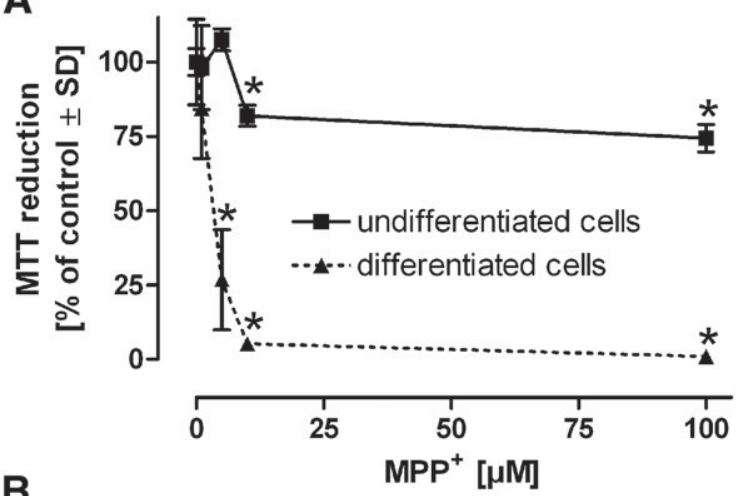

B

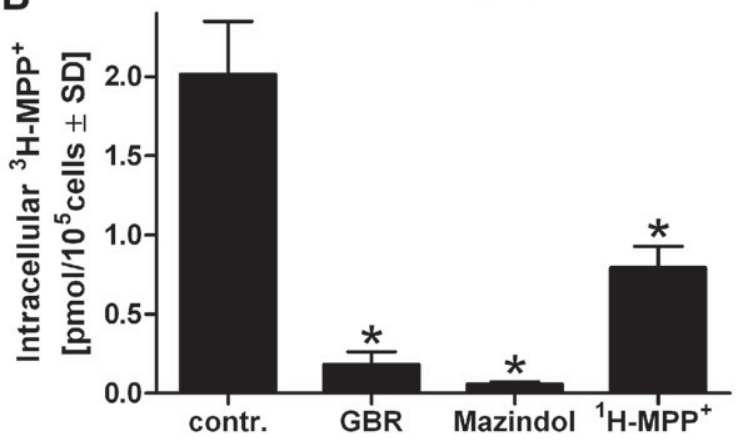

C

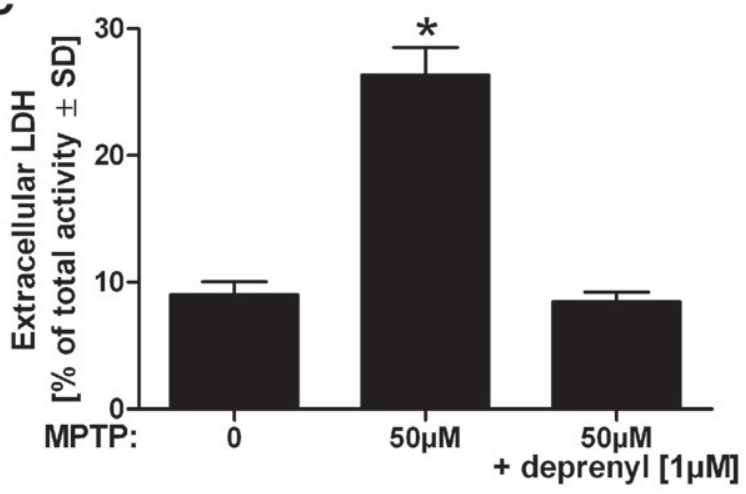

D

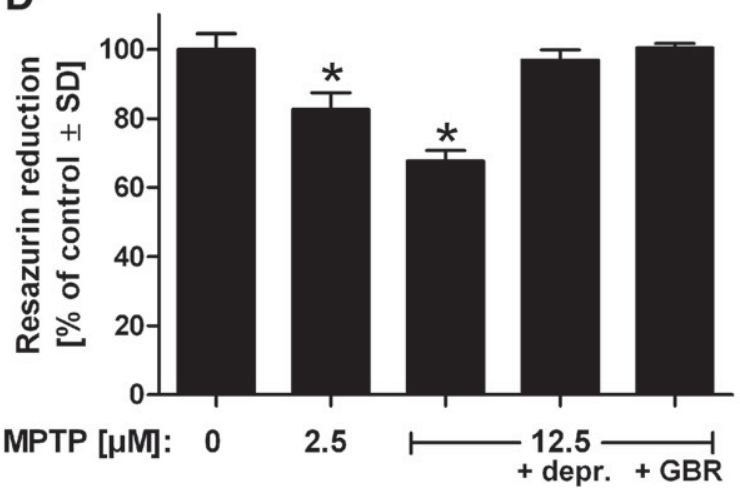

$\mathrm{MPP}^{+}$-induced loss of cell viability (MTT reduction) at their respective highest non-toxic concentration by approximately $50 \%$ (Figs. 6A, B). In the same experiments, intracellular ATP levels were hardly affected by $\mathrm{TH}$ inhibitors. This indicates that $\mathrm{MPP}^{+}$still reached the interior of the cells and showed its primary effect on mitochondrial complex I. This latter effect does not appear to depend on intracellular dopamine, and on the oxidative stress that would be caused by release of dopamine from vesicular stores. The partial restoration of intracellular GSH levels by $\mathrm{TH}$ inhibitors indicates a significant contribution of endogenous dopamine biosynthesis to oxidative stress conditions, and to the depletion of GSH, caused by $\mathrm{MPP}^{+}$(Figs. 6A, B).

In a different approach, it was tested whether pre-depletion of cellular dopamine by reserpine would affect $\mathrm{MPP}^{+}$toxicity (Lotharius and O'Malley, 2000; Obata, 2002). The VMAT-2 inhibitor reserpine was added to the culture medium $1 \mathrm{~h}$ before $\mathrm{MPP}^{+}$. Under these conditions, dopamine stores are continuously emptied, but cannot be refilled, and remaining cytosolic dopamine is lost by reverse action of the DAT (Kitayama et al., 1996; Sulzer et al., 1996). Indeed, a significantly improved viability and an attenuated decrease of cellular ATP and GSH levels by this treatment was observed. The effects were not further improved by additional inhibition of TH (Fig. 6C). These results provide further proof for our hypothesis, that cellular dopamine contributes to the toxicity of $\mathrm{MPP}^{+}$in LUHMES cells, while sequestration of $\mathrm{MPP}^{+}$into vesicles, as observed especially in rat neurons (Staal et al., 2000), may not be a significant detoxification mechanism in LUHMES cells.

\section{A potential role for the interaction of iron and $\mathrm{MPP}^{+}$in LUHMES toxicity}

In the methamphetamine model (Fig. 3) $\mathrm{Fe}^{2+}$ is a necessary factor for toxicity, and its depletion by desferal abolishes degeneration (Lotharius et al., 2005). As free iron may also play a role in enhancing parkinsonian neurodegeneration, its role was examined in the LUHMES/MPP ${ }^{+}$model. First, it was tested whether additional free iron would synergistically increase the toxicity of $\mathrm{MPP}^{+}$ $(5 \mu \mathrm{M})$. Viability parameters were detected already after $48 \mathrm{~h}$ in order to detect accelerated toxicity. Iron concentrations that were not toxic by themselves, significantly enhanced the effect of $\mathrm{MPP}^{+}$ on the viability parameters MTT reduction and ATP content, and thus accelerated the degeneration process (Fig. 7A). This finding suggests that oxidative stress would significantly contribute to the toxicity and energy depletion by $\mathrm{MPP}^{+}$in LUHMES cells. In order to test the role of endogenous free iron under the culture conditions employed, cells were incubated with $\mathrm{MPP}^{+}$in the presence of the iron chelator desferal. Viability and ATP content of the cells were increased compared to treatment with $\mathrm{MPP}^{+}$alone, but this effect was only partial and far from a complete protection (Fig. 7B). Thus, it appears that endogenous iron plays some role, but is not absolutely necessary for the manifestation of $\mathrm{MPP}^{+}$toxicity to LUHMES cells.

Fig. 4. Specific requirements for MPTP and $\mathrm{MPP}^{+}$toxicity to differentiated LUHMES cells. (A) Differentiated or undifferentiated LUHMES cells were exposed to $\mathrm{MPP}^{+}$at the concentrations indicated. After $72 \mathrm{~h}$, MTT reduction as indicator for cell viability was measured. (B) Differentiated LUHMES in 96-well plates were pre-treated with the DAT blockers GBR $12909(0.1 \mu \mathrm{M})$ or mazindol $(100 \mu \mathrm{M})$ for 30 min, followed by the addition of $15 \mathrm{nM}$ radiolabelled $\mathrm{MPP}^{+}\left({ }^{3} \mathrm{H}-\mathrm{MPP}^{+}\right)$in $5 \mu \mathrm{M}$ unlabelled $\mathrm{MPP}^{+}$for additional $20 \mathrm{~min}$. As further control, uptake experiments were performed in the presence of a 10fold excess $(50 \mu \mathrm{M})$ of non-labelled $\mathrm{MPP}^{+}\left({ }^{1} \mathrm{H}-\mathrm{MPP}^{+}\right)$. (C) Confluent rat glia cells were cultured in LUHMES-differentiation medium for $48 \mathrm{~h}$ in the absence or presence of MPTP or MPTP plus deprenyl $(1 \mu \mathrm{M})$. The supernatant was then added to LUHMES cultures as indicated and incubated for 3 days before LDH release was determined. N.B.: LDH activity released by glia cells was negligible (less than $5 \%$ ) compared with the activities in LUHMES supernatants. (D) The same experiment as in C was performed with lower MPTP concentrations, as indicated. As control for DAT-selective uptake of the glia-generated MPTP metabolite GBR $12909(0.1 \mu \mathrm{M})$ was co-incubated. Data are means $\pm S D$ of quadruplicates. 

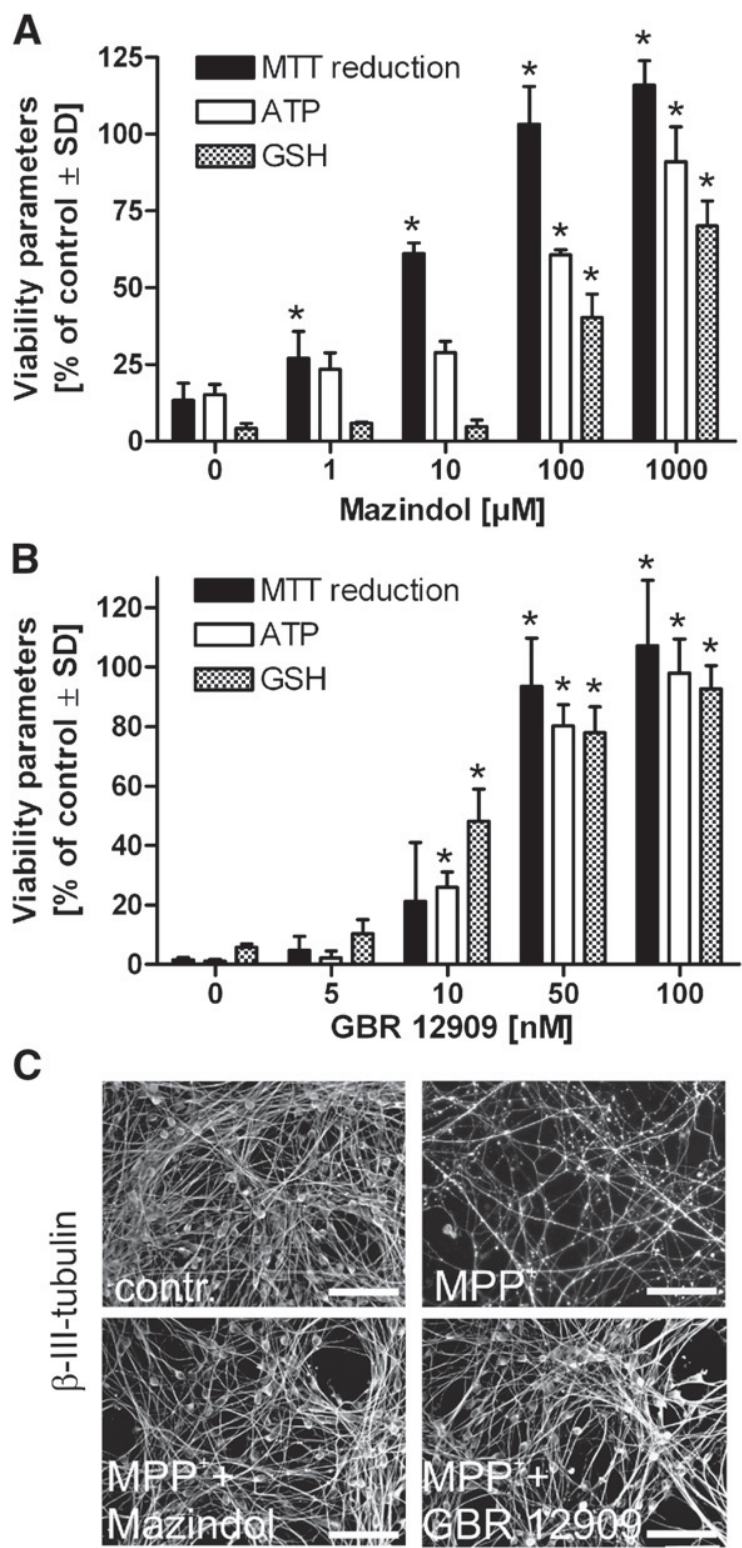

Fig. 5. Dependence of $\mathrm{MPP}^{+}$toxicity on functional dopamine transporter (DAT). LUHMES cells were differentiated and then exposed for $72 \mathrm{~h}$ to $\mathrm{MPP}^{+}(5 \mu \mathrm{M})$ or solvent (contr.). The DAT inhibitors (A) mazindol or (B) GBR 12909 were co-incubated with the toxicant at the concentrations indicated. At the end of the experiment, cell viability was determined by MTT reduction and intracellular levels of ATP and GSH were measured. Data are means $+\mathrm{SD}$ of quadruplicates. $*: p<0.05 \mathrm{MPP}^{+}$compared to $\mathrm{MPP}^{+}$plus inhibitor by Dunnet's post-hoc test after detection of significant overall group differences by ANOVA. (C) Cells treated with $\mathrm{MPP}^{+}$, or MPP ${ }^{+}$plus GBR 12909 were stained for $\beta$-III tubulin to visualize the integrity of soma and neurite structures. Scale bar: $100 \mu \mathrm{m}$.

Block of $\mathrm{MPP}^{+}$-driven degeneration by the mixed lineage kinase inhibitor CEP1347

The dopamine-dependent degeneration after exposure of LUHMES cells to $\mathrm{METH} / \mathrm{Fe}^{2+}$ has been shown to be blocked efficiently by the mixed lineage kinase inhibitor CEP1347 (Lotharius et al., 2005) even after the initial damage had occurred. As the $\mathrm{MPP}^{+}$model appears to share at least a partial dopamine dependence with the $\mathrm{METH} / \mathrm{Fe}^{2+}$ model, the impact of CEP1347 on $\mathrm{MPP}^{+}$toxicity was tested. CEP1347 concentrations of already $10 \mathrm{nM}$ resulted in a significant protection from $\mathrm{MPP}^{+}$-induced toxicity that was nearly completely blocked by $250 \mathrm{nM}$ (Figs. 8A, B). At CEP1347 concentrations of 100-250 nM, the increased viability was more or less paralleled by increased GSH concentrations to nearly $100 \%$ of control values. Interestingly, the effects on ATP levels were much less pronounced, and even the highest concentration of CEP1347 led only to a small increase of ATP to about $30 \%$ of untreated control cells (Fig. 8A). These findings suggest that an initial drop of ATP by $60-70 \%$ is a primary effect of $\mathrm{MPP}^{+}$, while secondary effects are responsible for the drop below the $30 \%$ threshold. Moreover, depletion of GSH was not a primary effect of $\mathrm{MPP}^{+}$but a downstream consequence of intracellular signaling events (i.e. MLK activation) triggered by the initial damage. Although $\mathrm{MPP}^{+}$accumulation in the cells and the resulting depletion of ATP was not blocked in the presence of CEP1347, the drop of GSH was largely prevented under these conditions. This finding indicates that the model is suited for the identification of pharmacological inhibitors
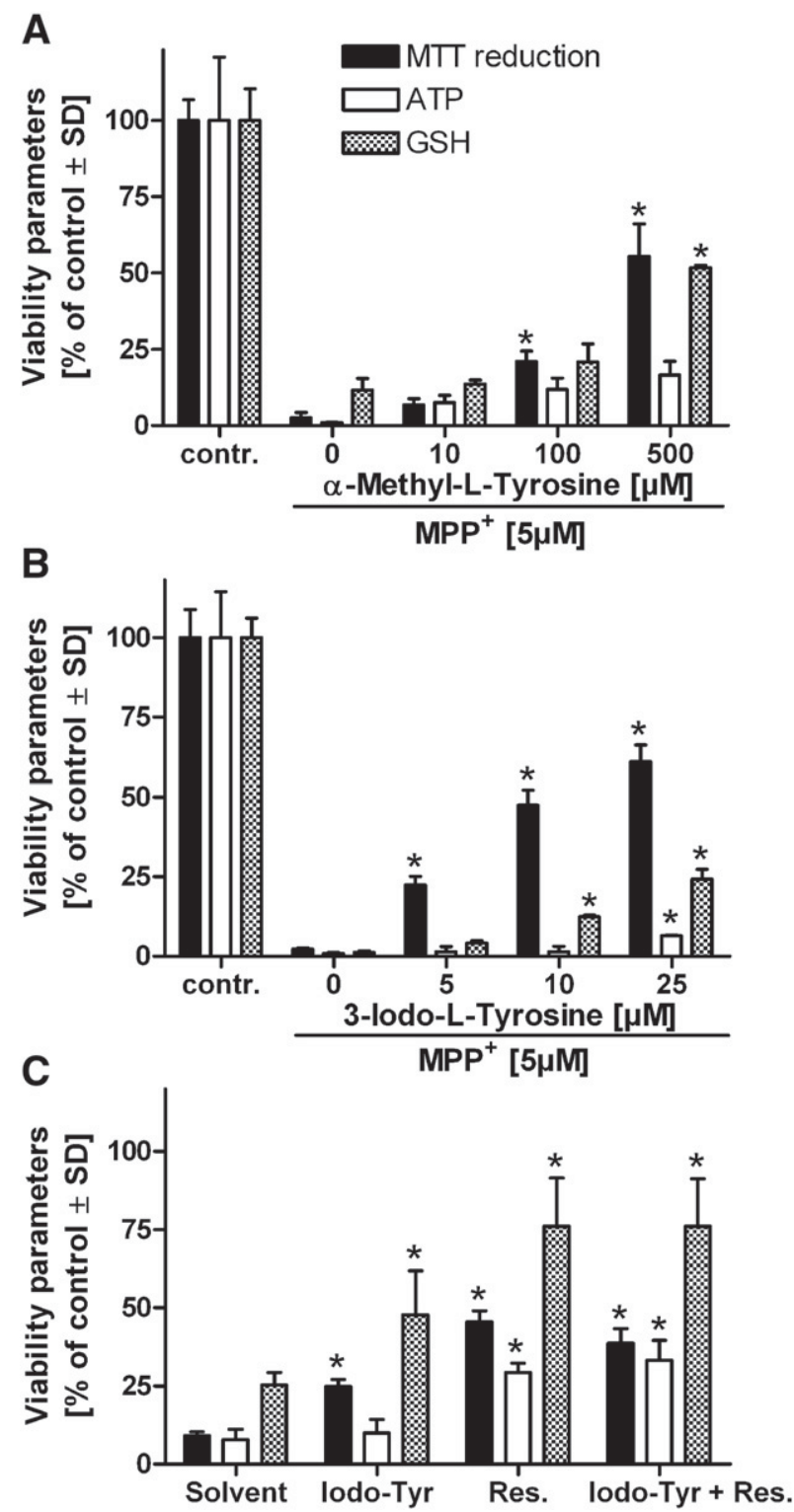

Fig. 6. The role of endogenous dopamine synthesis in $\mathrm{MPP}^{+}$toxicity to LUHMES cells. LUHMES cells were differentiated and then exposed for $72 \mathrm{~h}$ to $\mathrm{MPP}^{+}(5 \mu \mathrm{M})$ or solvent (contr.). The TH inhibitors (A) $\alpha$-methyl-L-tyrosine or (B) 3-iodo-L-tyrosine were coincubated with the toxicant at the concentrations indicated. At the end of the experiment, cell viability was determined by MTT reduction and intracellular levels of ATP and GSH were measured. (C) Reserpine (Res, $1 \mu \mathrm{M}$ ) or 3-iodo-t-tyrosine (Iodo-Tyr, $10 \mu \mathrm{M}$ ) or a combination of both were added to the cells for $1 \mathrm{~h}$, then MPP ${ }^{+}$was added for additional $72 \mathrm{~h}$. MTT reduction, ATP and GSH were measured at the end of the experiment. The inhibitors alone had no significant effect on any assay parameter. Data are means $\pm \mathrm{SD}$ of quadruplicates. $*: p<0.05 \mathrm{MPP}^{+}$compared to $\mathrm{MPP}^{+}$plus inhibitor by Dunnet's post-hoc test after detection of significant overall group differences by ANOVA. 
acting downstream of the uptake of $\mathrm{MPP}^{+}$and on the level of the dopaminergic target cell. In addition to CEP1347, also high concentrations of so-called pan-caspase inhibitors (e.g. z-VAD(-OMe)-fmk $(50 \mu \mathrm{M})$ or of the antioxidant sodium ascorbate $(1 \mathrm{mM})$ showed a similar target cell effect (not shown), and thus may be used as mechanistically diverse positive controls in a screen situation. Compounds that would rather be expected to act indirectly (e.g. via effects on glial cells or on transmitters derived from other cell types) were not effective in the model described here. These involved minocycline $(10 \mu \mathrm{M})$, the monoamine oxidase inhibitor deprenyl (up to $20 \mu \mathrm{M})$, the nitric oxide synthase inhibitor L-NMMA (1 mM), the cyclooxygenase inhibitor acetyl salicylic acid $(10 \mu \mathrm{M})$ and the NADPH oxidase inhibitor apocynin $(100 \mu \mathrm{M})$. Such compounds may be used as negative controls and showed the limitations of the assay system.

Live-cell multiparametric viability assay for further examination of $\mathrm{MPP}^{+}$toxicity to LUHMES cells

The LUHMES/MPP ${ }^{+}$model resembles many features of in vivo experimental systems and human PD and therefore represents an attractive system for the assessment of potential neuroprotective drug candidates or drug targets. For application in a high content screening format, LUHMES were seeded in 96-well plates at a density of 120,000 cells $/ \mathrm{cm}^{2}$ (40,000 cells/well). In order to quantify neurodegeneration, neurite mass (calcein-AM) and localization of energized mitochondria (TMRE) in neurites were evaluated. The detection of neurites and mitochondria was only performed in the non-somata cellular region
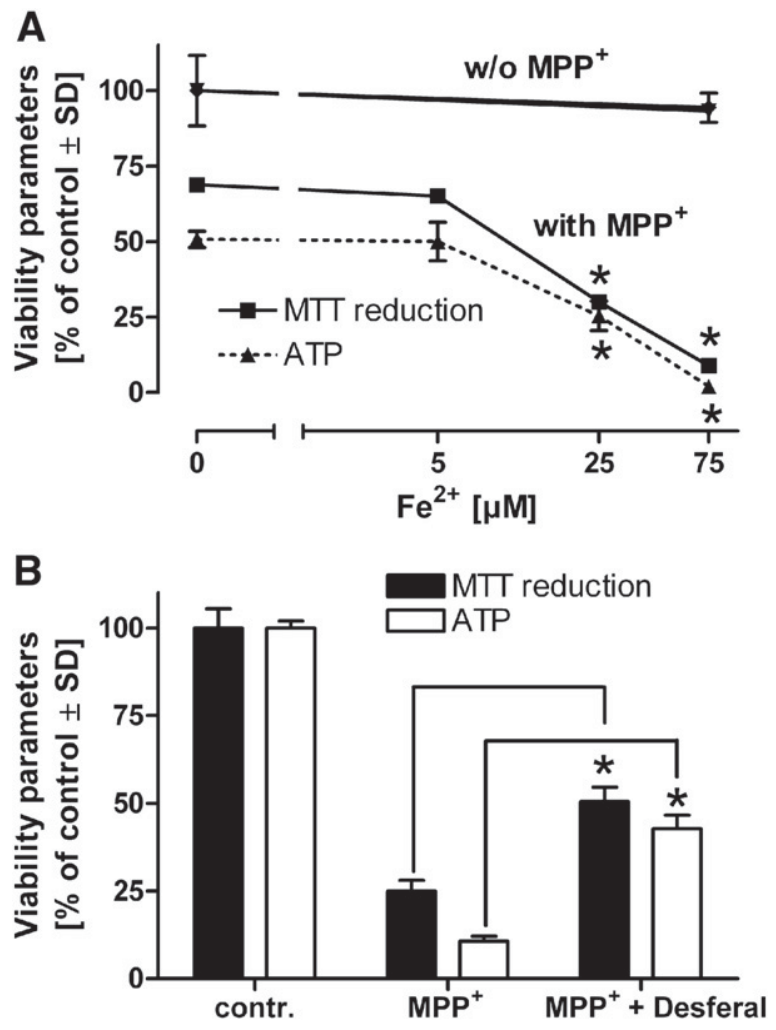

Fig. 7. Effects of free iron on $\mathrm{MPP}^{+}$toxicity to LUHMES cells. LUHMES cells were differentiated and then exposed for $48 \mathrm{~h}$ to $\mathrm{MPP}^{+}(5 \mu \mathrm{M})$ or solvent (contr.). (A) MPP ${ }^{+}$ treated cells were co-exposed to different concentrations of $\mathrm{Fe}^{2+}\left(\mathrm{FeCl}_{2}\right)$ as indicated, and viability (MTT reduction) as well as intracellular levels of ATP was examined. $\mathrm{Fe}^{2+}$ at the highest concentration $(75 \mu \mathrm{M})$ had no effect on any of the parameters when added alone. (B) Cells treated with or without $\mathrm{MPP}^{+}$were co-exposed to deferoxamine mesylate (Desferal, $100 \mu \mathrm{M})$. Cellular integrity was investigated by detection of cell viability (MTT) and intracellular levels of ATP. Desferal alone had no effect on any assay parameter. Data are means $\pm S D$ of quadruplicates. $*: p<0.05 \mathrm{MPP}^{+}$compared to $\mathrm{MPP}^{+}$ plus Desferal by $t$-test.

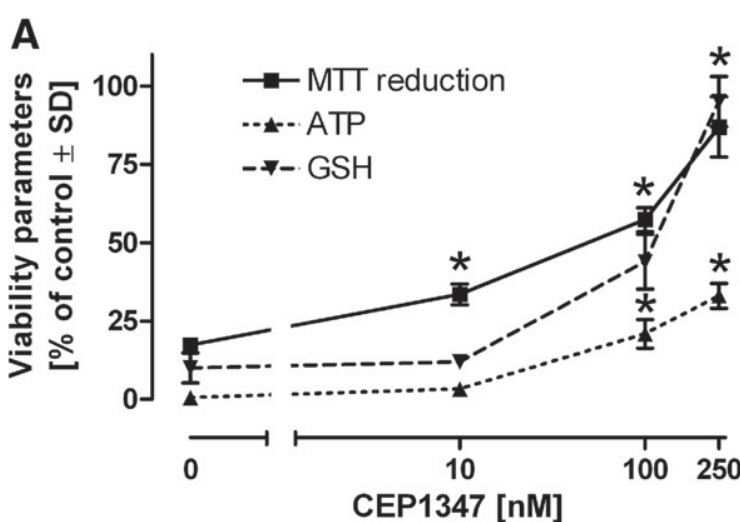

B

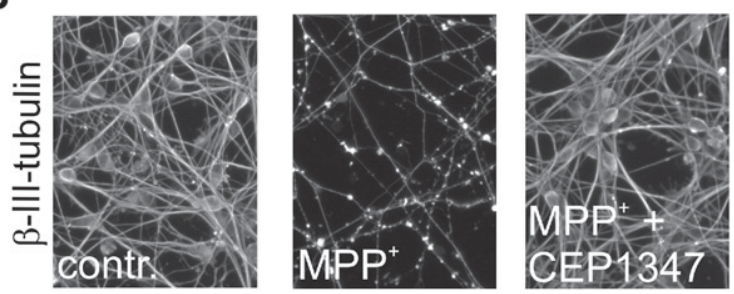

Fig. 8. Block of $\mathrm{MPP}^{+}$-mediated neurodegeneration by the mixed lineage kinase inhibitor CEP1347. (A) LUHMES cells were differentiated and then exposed for $72 \mathrm{~h}$ to $\mathrm{MPP}^{+}(5 \mu \mathrm{M})$ or solvent (contr.). CEP1347 was co-incubated with the toxicant at the concentrations indicated. The drug alone was non-toxic. At the end of the experiment, cell viability was determined by MTT reduction, and intracellular levels of ATP and GSH were measured. Data are means \pm SD of quadruplicates. *: $p<0.05 \mathrm{MPP}^{+}$compared to $\mathrm{MPP}^{+}$plus CEP1347 by Dunnet's post-hoc test after detection of significant overall group differences by one-way ANOVA. (B) Cells were treated by $\mathrm{MPP}^{+}$in the absence (left) or presence (right) of CEP1347 (250 nM) and stained for $\beta$-III tubulin. All neurites are fragmented and somata not recognizable anymore after $\mathrm{MPP}^{+}$treatment, while CEP1347 treatment maintained the neurite structure and allows recognition of a tubulin ring around each intact cell body.

(Fig. 9A). This procedure correlated quantitatively well with the visual impression of the neurite network at the cell density chosen. The results were more robust, than tracing of individual neurites, as the cells form a very dense network with neurites frequently crossing one another or overlapping with cell somata. For exclusion of the somata from analysis, the image analysis algorithm used defined an area around the identified $\mathrm{H}-33342$-positive nuclei as cell somata and excluded it. The method was sensitive enough to detect a drop in neurite mass already $24 \mathrm{~h}$ after $\mathrm{MPP}^{+}$exposure, and the gradual decline over time was easy to follow and quantify (Fig. 9B). In order to test the practical applicability of the method, the major pharmacological findings of this study were independently re-tested with the high content screening system. As expected, $\mathrm{MPP}^{+}(5 \mu \mathrm{M})$ caused an $80 \%$ drop in neurite mass and neurite mitochondrial mass. This toxicity was significantly attenuated by the DAT inhibitor GBR 12909 , the TH inhibitor $\alpha$-methyl-tyrosine or the MLK inhibitor CEP1347, while e.g. the stable prostacyclin analog iloprost showed no effect (Fig. 9C). After the imaging scan, viability of the same cells was measured in a classical way by the resazurin reduction assay and the data correlated well with the imaging results (Fig. 9C). These data confirm that the previous findings of this study are represented by neuronally-specific viability endpoints, and demonstrated the feasibility of a high content screen for compounds protecting against $\mathrm{MPP}^{+}$toxicity.

\section{Discussion}

In the present work, the dopaminergic neuron-like cell line LUHMES in combination with the parkinsonian toxin $\mathrm{MPP}^{+}$was characterized as new in vitro model for PD research. The relevance of the system is based on the human origin and the explicit dopaminergic 


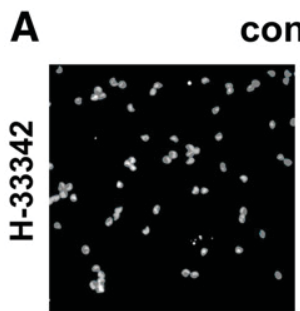

control
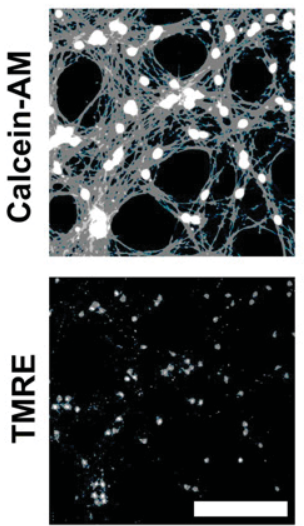

raw image
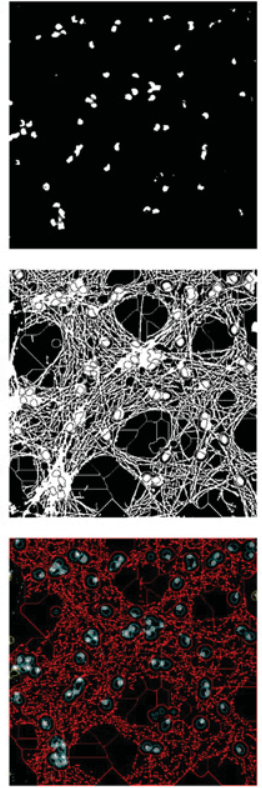

objects recognized
$\operatorname{MPP}^{+}[5 \mu \mathrm{M}]$
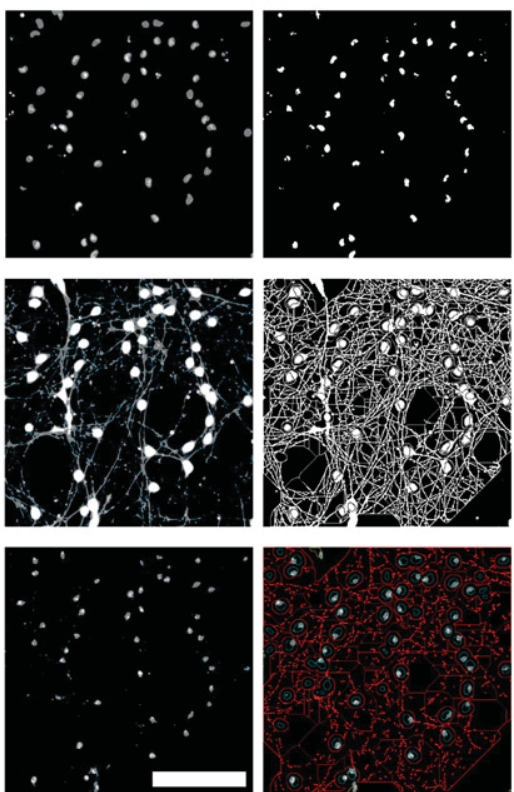

raw image

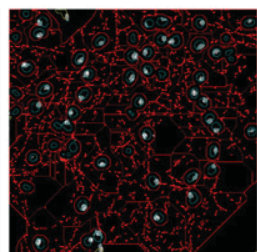

objects recognized

B
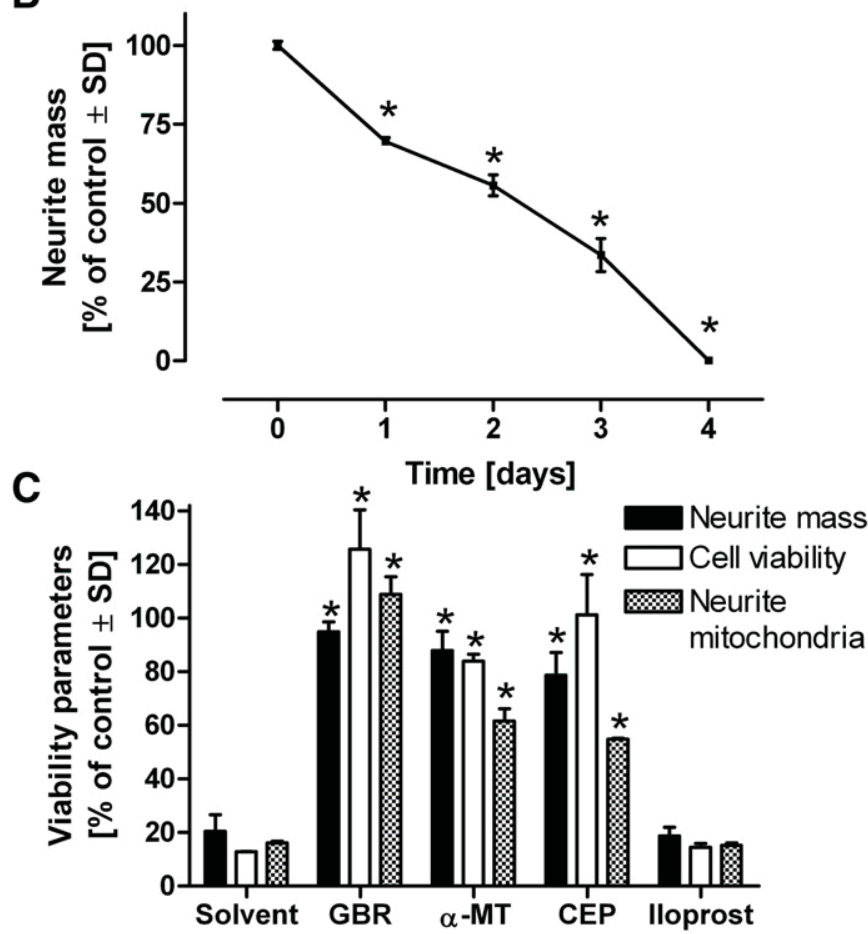

Fig. 9. Multiparametric viability screening on LUHMES cells exposed to $\mathrm{MPP}^{+}$. (A) Differentiated LUHMES were left untreated (left) or exposed to MPP ${ }^{+}$( $5 \mu \mathrm{M}$, right). Nuclei of live non-fixed cultures were stained with $\mathrm{H}-33342$ (top) and identified by the Cellomics ${ }^{\circledR}$ software; a segmentation procedure defined areas of the field "belonging" to individual nuclei as cell somata or as area of the neurites. Neurite areas of cells in contact with the border of an image were automatically excluded by the software and not analysed further (visible in middle and bottom). Somata areas were generally excluded from the further analysis. Live, membrane enclosed cellular structures (neurites and somata) were stained with calceinAM (middle images). The sum of detected calcein-positive pixels of the neurite areas from ten fields was calculated and defined as "neurite mass". Energized mitochondria were stained by TMRE and also detected solely in the neurite areas (bottom). The sum of their area over ten fields was defined as "neurite mitochondria mass". (B) Differentiated LUHMES were seeded in 96-well plates and exposed to $\mathrm{MPP}^{+}(5 \mu \mathrm{M})$ for the times indicated. Each day the neurite mass was determined and plotted as percentage of the neurite mass of untreated cells of the same age. (C) Differentiated LUHMES were plated in 96-well plates and exposed to MPP ${ }^{+}(5 \mu \mathrm{M})$ for $72 \mathrm{~h}$. Data for neurite mass, neurite mitochondria mass and viability (resazurin reduction) are expressed relative to those of untreated control cells. In addition to $\mathrm{MPP}^{+}$alone (solvent) cells were co-incubated with MPP ${ }^{+}$plus $1 \mu \mathrm{M}$ GBR 12909 (GBR), $500 \mu \mathrm{M} \alpha$-methyl-L-tyrosine ( $\alpha$-MT), $250 \mathrm{nM}$ CEP1347 (CEP) or $1 \mu \mathrm{M}$ iloprost. Data are means \pm SD of quadruplicates. 
phenotype of the cells, allowing to observe events at $\mathrm{MPP}^{+}$ concentrations representative for those observed in animal models or man.

\section{Role of DA phenotype}

One of the major findings of this study is the close dependency of $\mathrm{MPP}^{+}$-mediated toxicity on the dopaminergic phenotype of LUHMES cells. At first sight one may assume that the presence of the DAT alone is sufficient to explain the selective damage by $\mathrm{MPP}^{+}$for dopaminergic neurons. However, also low doses of systemically administered rotenone lead to a selective degeneration of dopaminergic neurons (Betarbet et al., 2000). Since no selectivity in uptake or accumulation of rotenone in DA neurons is known so far, this observation strongly indicates additional mechanisms leading to a relatively specific neurite degeneration and cell death in the Substantia nigra/striatum. The primary candidate for the observed sensitivity is DA, that can be rapidly autoxidized to form reactive quinones, that, together with iron, mediate the formation of reactive oxygen species (Stokes et al., 1999; Lotharius and O'Malley, 2000).

LUHMES are a subclone of the earlier described MESC2.10 cells (Lotharius et al., 2002). Interestingly, both culture systems show pronounced differences in $\mathrm{MPP}^{+}$toxicity, most likely depending on the differentiation state and culture conditions. The LUHMES cells follow a very defined and homogeneous differentiation pathway, and are killed by $\mathrm{MPP}^{+}$concentrations as low as $5 \mu \mathrm{M}$ after prolonged incubation $(72 \mathrm{~h})$. They were also killed within only one day by $\mathrm{MPP}^{+}$ concentrations of 50-100 $\mu \mathrm{M}$, while MESC2.10 cells appear very resistant to $\mathrm{MPP}^{+}$(Fountaine et al., 2008). Even millimolar concentrations resulted only in a moderate decline in cell viability after $16 \mathrm{~h}$ in the latter cells. The necessity of a differentiated dopaminergic phenotype for the MPP ${ }^{+}$effects observed in our study was confirmed by our observation of the resistance of non-differentiated LUHMES to $\mathrm{MPP}^{+}$up to $100 \mu \mathrm{M}$ even after extended incubation periods.

Since passive diffusion of the charged molecule $\mathrm{MPP}^{+}$over plasma membranes plays only a minor role for toxicity at concentrations of $5 \mu \mathrm{M}$, the toxicity of $\mathrm{MPP}^{+}$observed at low micromolar concentrations required a specific transport process. We provide unequivocal evidence in this study for the role of the DAT, and thus the dopaminergic phenotype, for all viability parameters investigated. This distinguishes the LUHMES model from many other cell culture models, e.g. using SH-SY5Y neuroblastoma cells, and is in good agreement with literature findings demonstrating that knockout of the DAT completely protects from $\mathrm{MPP}^{+}$toxicity (Bezard et al., 1999), while toxicity is enhanced by DAT overexpression (Kitayama et al., 1992; Pifl et al., 1993).

A significant contribution of DA to $\mathrm{MPP}^{+}$-mediated toxicity was indicated by our observation that the loss of ATP, GSH, and cell viability is attenuated by the tyrosine hydroxylase inhibitors $\alpha$ methyl-L-tyrosine and 3-iodo-L-tyrosine. Thus, on the one hand oxidative stress, related to dopamine metabolism, may synergize with the energy loss evoked by the inhibition of mitochondrial respiration. On the other hand, the damage still observed after block of DA synthesis and vesicular uptake indicates that a sizable fraction of $\mathrm{MPP}^{+}$toxicity is independent of the cellular dopamine content, once the toxicant has been accumulated by the DAT.

It was previously reported that $\mathrm{MPP}^{+}$may be sequestered into dopaminergic vesicles by VMAT-2. This process is particularly pronounced in rat neurons (Staal et al., 2000) and may contribute to a relative resistance of rats to $\mathrm{MPP}^{+}$toxicity. In our system, the VMAT-2 inhibitors reserpine or tetrabenazine definitely did not reduce $\mathrm{MPP}^{+}$toxicity (not shown). Thus, this type of sequestration may not play a major role in LUHMES cells. Rather on the opposite, reserpine attenuated $\mathrm{MPP}^{+}$toxicity when cells were treated with the inhibitor before exposure to the toxicant. A protective effect by VMATdependent sequestration of MPP ${ }^{+}$is unlikely in the LUHMES system, as we did not work with limiting conditions of MPP. In fact, uptake measurements with radioactive $\mathrm{MPP}^{+}$showed, that after $30 \mathrm{~min}$, already half of the maximum amount was taken up, and after 60 min saturation was reached. Sequestration of some of the $\mathrm{MPP}^{+}$to vesicles would be easily compensated in this system and should not be expected despite the relatively low concentrations used. Even sequestration of $10-20 \%$ of the entire $\mathrm{MPP}^{+}$in the culture well into neurotransmitter vesicles would hardly have affected the overall toxicity readout. The action of reserpine in our model may be explained by its DA-depleting function. This would prevent the welldescribed rapid release of DA from vesicles into the cytosol and extracellular space upon $\mathrm{MPP}^{+}$exposure (Pileblad and Carlsson, 1985; Sirinathsinghji et al., 1988), and prevent cell sensitization in our study by DA autoxidation. These observations are in good agreement with findings from an in vitro model of primary mouse DA neurons (Lotharius and O'Malley, 2000). There, depletion of DA almost completely prevented $\mathrm{MPP}^{+}$toxicity, indicating a significant role of endogenous DA in $\mathrm{MPP}^{+}$toxicity to primary neurons. However, the situation appears more complicated in vivo. A number of manipulations reducing striatal dopamine did not protect from MPTP toxicity in mice (Hasbani et al., 2005). The potential role of DA may be masked in such acute in vivo studies by the relatively stronger antioxidative capacity. The major neuronal redox buffer glutathione is provided by glial cells (Wullner et al., 1996; Dringen et al., 1999), and the better supply in intact tissue may support cells to buffer stress triggered by DA. Accordingly, mice and rats are sensitized to $\mathrm{MPP}^{+}$under conditions of GSH depletion (Wullner et al., 1996). In disease models in animals, also non-cell autonomous mechanisms may contribute to $\mathrm{MPTP} / \mathrm{MPP}^{+}$toxicity and dominate the role of endogenous dopamine. These cell-cell interactions may include the contribution of excitotoxicity (Leist et al., 1998; Sonsalla et al., 1998) and inflammation (Hald et al., 2007; Zhou et al., 2008). The general contribution of DA to toxicity in vivo may depend on a variety of factors not only in the MPTP model, but also after METH-induced degeneration of dopaminergic neurites and in PD (Lotharius and Brundin, 2002). VMAT-2 activity, for instance, could play a role. When the activity of this transporter was changed, by overexpression or knockdown, then toxicity in various in vitro and in vivo models correlated with the effects of VMAT-2 manipulation on cytosolic dopamine (Staal and Sonsalla, 2000; Vergo et al., 2007; Gainetdinov et al., 1998; Guillot and Miller, 2009).

The relative selectivity of $\mathrm{MPP}^{+}$toxicity to S. nigra neurons (as opposed to several other groups of catecholaminergic neurons) certainly requires further explanations, than the presence of DA alone. One that has been frequently discussed is a difference in iron metabolism. When LUHMES were treated with methamphetamine, that acts as a potent trigger of DA release, the presence of $\mathrm{Fe}^{2+}$ was essential for neurodegeneration (Lotharius et al., 2005). Iron acts as a catalyst in the Fenton reaction and thereby is vitally involved in the conversion of mild oxygen radical species to the highly reactive hydroxyl radical (Hald et al., 2007). This reaction may be initiated by dopamine-quinones formed rapidly as soon as DA is exposed to physiological buffer, $\mathrm{pH}$, and $\mathrm{O}_{2}$ conditions. Our finding that $\mathrm{Fe}^{2+}$ acts synergistically with $\mathrm{MPP}^{+}$-treatment to trigger a loss of LUHMES viability, may hint to the significant role of radical formation in the LUHMES $/ \mathrm{MPP}^{+}$model. It remains to be elucidated whether the initial radical formation originates mostly from DA-quinones or from the mitochondrial respiratory chain. Interestingly, desferal, an iron chelator, lead to a moderate, but significant improvement of cell viability and ATP levels. This indicates a basal modulating role of free endogenous iron, even without external addition.

\section{$\mathrm{MPP}^{+}$as inhibitor of mitochondrial respiration}

$\mathrm{MPP}^{+}$was described to primarily inhibit complex I of the mitochondrial respiratory chain (Richardson et al., 2007), even 
though this has been challenged recently (Choi et al., 2008). The relative contribution of cellular energy deprivation and DA-mediated oxidative stress appears to depend strongly on the respective system investigated (see above), but inhibition of mitochondrial ATP generation has been clearly and repeatedly demonstrated in isolated mitochondria, DA neuron cell cultures and in vivo (Mizuno et al., 1987; Mizuno et al., 1988). In the LUHMES model, $\mathrm{MPP}^{+}$resulted in a pronounced drop in intracellular ATP levels. The $24 \mathrm{~h}$ lag period prior to the decline is most likely explained by a requirement for accumulation of the toxicant until millimolar concentrations are reached in mitochondria (Singer et al., 1988). Interestingly, the initial drop of ATP was not prevented by CEP1347 or inhibition of TH. This may indicate a mode of action of $\mathrm{MPP}^{+}$, that is initially dominated by direct effects on mitochondrial complex I. This initial inhibition of mitochondria, may then trigger stress pathways involving the activation of mixed lineage kinases and oxidative stress (possibly linked to DA). These stress pathways and oxidative stress would then lead to a secondary drop of ATP, e.g. by irreversible inactivation of enzymes or damage to cellular structures. The relative contribution of different mechanisms could depend e.g. on the time point of analysis, the cell density used, or the $\mathrm{MPP}^{+}$concentration added. Such findings may not only apply to LUHMES cells, but also various other models of $\mathrm{MPTP} / \mathrm{MPP}^{+}$toxicity.

\section{Involvement of the mixed lineage kinase pathway in $\mathrm{MPP}^{+}$toxicity}

The second major pharmacological finding in our LUHMES/MPP ${ }^{+}$ model was the pronounced protection by the mixed lineage kinase inhibitor CEP1347. This is in agreement with in vivo findings in the MPTP model (Saporito et al., 1999), and also the protection by CEP1347 against METH/ $/ \mathrm{Fe}^{2+}$ induced toxicity (Lotharius et al., 2005). A similar protection was not observed in the PRECEPT (2007) study, testing neuroprotective properties in early-stage PD patients. However, this study did unfortunately not provide data on the CSF levels of CEP1347. For us, it was very important to obtain here the basic proofof-principle, that the LUHMES/MPP ${ }^{+}$model is accessible to pharmacological modulation, even after $\mathrm{MPP}^{+}$has accumulated in the neurons. Notably, CEP1347 does not interact with the DAT at concentrations up to $10 \mu \mathrm{M}$ (not shown). These findings of pharmacological protection of LUHMES from $\mathrm{MPP}^{+}$clearly suggest that mitochondrial inhibition alone was not sufficient for degeneration of the cells. This leaves hope for the future, that other pharmacological interventions are discovered, that can halt cell death even after initial damage has occurred.

\section{Neuron-specific endpoints of toxicity and single cell imaging}

The model described herein offers some additional features important for future pharmacological work. First, events can be imaged in single neuron-like cells or subcellular structures. This was shown here by staining for the mitochondrial membrane potential and staining with the vital dye calcein-AM, and may be expanded e.g. to calcium imaging. Such staining would be extremely cumbersome or virtually impossible in primary cultures prepared from embryonic ventral mesencephalon, if no better methods are found to identify live dopaminergic neurons. Second, metabolic changes can be followed for the relevant neuronal cell population, as demonstrated here for GSH, ATP, or malondialdehyde. This is hardly possible in primary cultures, where the relevant dopaminergic population may often be as low as $1-2 \%$ of the total cell population. Third, neuronal-specific endpoints, like the reduction of the neurite mass, were measured here with an automated screen procedure. Such endpoints are sometimes problematic in neuroblastoma cells, and they are very time consuming to evaluate in primary cultures, that need to be fixed and stained for $\mathrm{TH}$ (Boll et al., 2004). In a previous study (Lotharius et al., 2005) we made use of the fact that all LUHMES neurites express $\beta$-III tubulin, and we developed an algorithm to evaluate the neurite mass based on the staining of fixed cells for $\beta$-III tubulin (Lotharius et al., 2005). Although this method is very sensitive at low damage, it yields too high neurite mass values at higher damage intensities, because also dead fragments of neurites stain positive for the antigen. For this reason a new live staining method was developed, that identifies only viable neurite structures and does not lead to an underestimation of damage at prolonged toxicant concentrations (Fig. 7B). This method now enables sensitive and easy testing with an unbiased automated procedure. Technical difficulties associated with the fragile nature of neurites during fixation and staining procedures are also limited by this method. Notably, adaptation of this method to 96-well plates required $40 \%$ lower cell densities, than those described for 24 -well plates to allow optimal image processing. During these adaptation experiments we realized that $\mathrm{MPP}^{+}$toxicity depended on the cell density, and was more pronounced in denser cultures. Therefore, quantification was sometimes performed in 96-well cultures after 4 days of incubation to obtain the same results as found after $72 \mathrm{~h}$ in 24 well cultures. Some variations in cell density also caused slightly different extents of toxicity in 24-well cultures. However, data were always quantitatively highly consistent within one experiment, qualitative differences between different experiments in 24-well or 96-well cultures were not observed. A quantitative assessment of both conditions revealed similar results with respect to the degree of cell degeneration in response to $\mathrm{MPP}^{+}$and the impact of the respective pharmacological compounds applied in this work.

With respect to the usefulness of the model system described here, it is important to note that it will most likely fail to detect protective compounds that require other cell types such as astrocytes, microglia, other neurons or microvascular endothelial cells for their mode of action. For instance neuroprotective effects by modulation of proinflammatory mediators such as cytokines, eicosanoids or reactive oxygen species cannot be observed with a pure dopaminergic neuronal culture. They may possibly be simulated in a more advanced system that combines LUHMES cells with e.g. glial cells or an in vitro model of the blood-brain barrier.

\section{Outlook}

For a closer insight e.g. into the role and actions of cellular DA pools, $\alpha$-synuclein, and antioxidant enzymes such as Mn-SOD or peroxiredoxins, the model will be made available to all interested parties. An especially important task for the future will be the development of genetic intervention strategies to enable a selective up- or downregulation of genes of interest.

\section{Acknowledgments}

We are indebted to many colleagues for valuable contributions and insightful discussions during the course of this work. The antibody to ASYN was generously provided by P.H. Jensen (Aarhus, DK). D.M.N. and D.S. were funded by a special grant of the IRTG1331 and D.P. by KoRS-CB. B. Schimmelpfennig and R. Pape provided excellent technical assistance. Nathalie Schmieg and Judith Finkbeiner contributed during their bachelor thesis. The work was facilitated by grants from the Doerenkamp-Zbinden foundation, the Land Baden-Württemberg and the DFG.

\section{References}

Berg, D., Hochstrasser, H., 2006. Iron metabolism in Parkinsonian syndromes. Mov. Disord. 21, 1299-1310.

Betarbet, R., Sherer, T.B., MacKenzie, G., Garcia-Osuna, M., Panov, A.V., Greenamyre, J.T., 2000. Chronic systemic pesticide exposure reproduces features of Parkinson's disease. Nat. Neurosci. 3, 1301-1306.

Bezard, E., Gross, C.E., Fournier, M.C., Dovero, S., Bloch, B., Jaber, M., 1999. Absence of MPTP-induced neuronal death in mice lacking the dopamine transporter. Exp. Neurol. 155, 268-273. 
Boll, J.B., Geist, M.A., Kaminski Schierle, G.S., Petersen, K., Leist, M., Vaudano, E., 2004. Improvement of embryonic dopaminergic neurone survival in culture and after grafting into the striatum of hemiparkinsonian rats by CEP-1347. J. Neurochem. 88, 698-707.

Carrasco, E., Werner, P., 2002. Selective destruction of dopaminergic neurons by low concentrations of 6-OHDA and MPP+: protection by acetylsalicylic acid aspirin. Parkinsonism. Relat. Disord. 8, 407-411.

Choi, W.S., Kruse, S.E., Palmiter, R.D., Xia, Z., 2008. Mitochondrial complex I inhibition is not required for dopaminergic neuron death induced by rotenone, MPP + , or paraquat. Proc. Natl. Acad. Sci. U. S. A. 105, 15136-15141.

Di Monte, D., Ekstrom, G., Shinka, T., Smith, M.T., Trevor, A.J., Castagnoli Jr, N., 1987. Role of 1-methyl-4-phenylpyridinium ion formation and accumulation in 1-methyl-4phenyl-1,2,3,6-tetrahydropyridine toxicity to isolated hepatocytes. Chem. Biol. Interact. 62, 105-116.

Dringen, R., Kussmaul, L., Gutterer, J.M., Hirrlinger, J., Hamprecht, B., 1999. The glutathione system of peroxide detoxification is less efficient in neurons than in astroglial cells. J. Neurochem. 72, 2523-2530.

Fountaine, T.M., Venda, L.L., Warrick, N., Christian, H.C., Brundin, P., Channon, K.M., Wade-Martins, R., 2008. The effect of alpha-synuclein knockdown on MPP+ toxicity in models of human neurons. Eur. J. Neurosci. 28, 2459-2473.

Gainetdinov, R.R., Fumagalli, F., Wang, Y.M., Jones, S.R., Levey, A.I., Miller, G.W., Caron, M.G., 1998. Increased MPTP neurotoxicity in vesicular monoamine transporter 2 heterozygote knockout mice. J. Neurochem. 70 (5), 1973-1978.

Gartlon, J., Kinsner, A., Bal-Price, A., Coecke, S., Clothier, R.H., 2006. Evaluation of a proposed in vitro test strategy using neuronal and non-neuronal cell systems for detecting neurotoxicity. Toxicol. In. Vitro. 20, 1569-1581.

Grimsby, J., Toth, M., Chen, K., Kumazawa, T., Klaidman, L., Adams, J.D., Karoum, F., Gal, J., Shih, J.C., 1997. Increased stress response and beta-phenylethylamine in MAOBdeficient mice. Nat. Genet. 17, 206-210.

Guillot, T.S., Miller, G.W., 2009. Protective actions of the vesicular monoamine transporter 2 (VMAT2) in monoaminergic neurons. Mol. Neurobiol. 39 (2), 149-170.

Hald, A., Van Beek, J., Lotharius, J., 2007. Inflammation in Parkinson's disease: causative or epiphenomenal? Subcell. Biochem. 42, 249-279.

Hasbani, D.M., Perez, F.A., Palmiter, R.D., O'Malley, K.L., 2005. Dopamine depletion does not protect against acute 1-methyl-4-phenyl-1,2,3,6-tetrahydropyridine toxicity in vivo. J. Neurosci. 25, 9428-9433.

Heikkila, R.E., Manzino, L., Cabbat, F.S., Duvoisin, R.C., 1984. Protection against the dopaminergic neurotoxicity of 1-methyl-4-phenyl-1,2,5,6-tetrahydropyridine by monoamine oxidase inhibitors. Nature 311, 467-469.

Jakowec, M.W., Petzinger, G.M., 2004. 1-methyl-4-phenyl-1,2,3,6-tetrahydropyridinelesioned model of Parkinson's disease, with emphasis on mice and nonhuman primates. Comp. Med. 54, 497-513.

Javitch, J.A., D'Amato, R.J., Strittmatter, S.M., Snyder, S.H., 1985. Parkinsonism-inducing neurotoxin, N-methyl-4-phenyl-1,2,3,6-tetrahydropyridine: uptake of the metabolite N-methyl-4-phenylpyridine by dopamine neurons explains selective toxicity. Proc. Natl. Acad. Sci. U. S. A. 82, 2173-2177.

Kaneko, M., Saito, Y., Saito, H., Matsumoto, T., Matsuda, Y., Vaught, J.L., Dionne, C.A., Angeles, T.S., Glicksman, M.A., Neff, N.T., Rotella, D.P., Kauer, J.C., Mallamo, J.P., Hudkins, R.L., Murakata, C., 1997. Neurotrophic 3,9-bis[(alkylthio)methyl]-and-bis (alkoxymethyl)-K-252a derivatives. J. Med. Chem. 40, 1863-1869.

Kitayama, S., Shimada, S., Uhl, G.R., 1992. Parkinsonism-inducing neurotoxin MPP+: uptake and toxicity in nonneuronal COS cells expressing dopamine transporter cDNA. Ann. Neurol. 32, 109-111.

Kitayama, S., Morita, K., Dohi, T., 1996. Uptake and release of dopamine through the rat dopamine transporter expressed in Xenopus laevis oocyte: evaluation by voltammetric measurement of intracellular dopamine concentration. Neurosci. Lett. 211, 132-134.

Langston, J.W., Ballard, P., Tetrud, J.W., Irwin, I., 1983. Chronic Parkinsonism in humans due to a product of meperidine-analog synthesis. Science $219,979-980$

Langston, J.W., Irwin, I., Langston, E.B., Forno, L.S., 1984. 1-Methyl-4-phenylpyridinium ion (MPP+): identification of a metabolite of MPTP, a toxin selective to the substantia nigra. Neurosci. Lett. 48, 87-92.

Leist, M., Volbracht, C., Fava, E., Nicotera, P., 1998. 1-Methyl-4-phenylpyridinium induces autocrine excitotoxicity, protease activation, and neuronal apoptosis. Mol. Pharmacol. 54, 789-801.

Litvan, I., Chesselet, M.F., Gasser, T., Di Monte, D.A., Parker Jr., D., Hagg, T., Hardy, J., Jenner, P., Myers, R.H., Price, D., Hallett, M., Langston, W.J., Lang, A.E., Halliday, G., Rocca, W., Duyckaerts, C., Dickson, D.W., Ben-Shlomo, Y., Goetz, C.G., Melamed, E., 2007a. The etiopathogenesis of Parkinson disease and suggestions for future research. Part II. J. Neuropathol. Exp. Neurol. 66, 329-336.

Litvan, I., Halliday, G., Hallett, M., Goetz, C.G., Rocca, W., Duyckaerts, C., Ben-Shlomo, Y., Dickson, D.W., Lang, A.E., Chesselet, M.F., Langston, W.J., Di Monte, D.A., Gasser, T., Hagg, T., Hardy, J., Jenner, P., Melamed, E., Myers, R.H., Parker Jr., D., Price, D.L., 2007b. The etiopathogenesis of Parkinson disease and suggestions for future research. Part I. J. Neuropathol. Exp. Neurol. 66, 251-257.

Lotharius, J., Brundin, P., 2002. Pathogenesis of Parkinson's disease: dopamine, vesicles and alpha-synuclein. Nat. Rev. Neurosci. 3, 932-942.

Lotharius, J., O'Malley, K.L., 2000. The parkinsonism-inducing drug 1-methyl-4phenylpyridinium triggers intracellular dopamine oxidation. A novel mechanism of toxicity. J. Biol. Chem. 275, 38581-38588.

Lotharius, J., Barg, S., Wiekop, P., Lundberg, C., Raymon, H.K., Brundin, P., 2002. Effect of mutant alpha-synuclein on dopamine homeostasis in a new human mesencephalic cell line. J. Biol. Chem. 277, 38884-38894.

Lotharius, J., Falsig, J., van Beek, J., Payne, S., Dringen, R., Brundin, P., Leist, M., 2005 Progressive degeneration of human mesencephalic neuron-derived cells triggered by dopamine-dependent oxidative stress is dependent on the mixed-lineage kinase pathway. J. Neurosci. 25, 6329-6342.

Markey, S.P., Johannessen, J.N., Chiueh, C.C., Burns, R.S., Herkenham, M.A., 1984 Intraneuronal generation of a pyridinium metabolite may cause drug-induced parkinsonism. Nature 311, 464-467.

Meissner, W., Prunier, C., Guilloteau, D., Chalon, S., Gross, C.E., Bezard, E., 2003. Timecourse of nigrostriatal degeneration in a progressive MPTP-lesioned macaque model of Parkinson's disease. Mol. Neurobiol. 28, 209-218.

Mizuno, Y., Suzuki, K., Sone, N., Saitoh, T., 1987. Inhibition of ATP synthesis by 1-methyl4-phenylpyridinium ion (MPP+) in isolated mitochondria from mouse brains. Neurosci. Lett. 81, 204-208.

Mizuno, Y., Sone, N., Suzuki, K., Saitoh, T., 1988. Studies on the toxicity of 1-methyl-4 phenylpyridinium ion (MPP+) against mitochondria of mouse brain. J. Neurol. Sci. $86,97-110$

Obata, T., 2002. Dopamine efflux by MPTP and hydroxyl radical generation. J. Neural. Transm. 109, 1159-1180.

Paul, G., Christophersen, N.S., Raymon, H., Kiaer, C., Smith, R., Brundin, P., 2007. Tyrosine hydroxylase expression is unstable in a human immortalized mesencephalic cell line-studies in vitro and after intracerebral grafting in vivo. Mol. Cell. Neurosci. 34, 390-399.

Pifl, C., Giros, B., Caron, M.G., 1993. Dopamine transporter expression confers cytotoxicity to low doses of the parkinsonism-inducing neurotoxin 1-methyl-4 phenylpyridinium. J. Neurosci. 13, 4246-4253.

Pileblad, E Carlsson, A 1985. Catecholamine-uptake inhibitors prevent the neurotoxicity of 1-methyl-4-phenyl-1,2,3,6-tetrahydropyridine (MPTP) in mouse brain. Neuropharmacology 24, 689-692.

PRECEPT, 2007. Mixed lineage kinase inhibitor CEP-1347 fails to delay disability in early Parkinson disease. Neurology 69, 1480-1490.

Ramsay, R.R., Singer, T.P., 1986. Energy-dependent uptake of N-methyl-4-phenylpyridinium, the neurotoxic metabolite of 1-methyl-4-phenyl-1,2,3,6-tetrahydropyridine, by mitochondria. J. Biol. Chem. 261, 7585-7587.

Ramsay, R.R., Krueger, M.J., Youngster, S.K., Gluck, M.R., Casida, J.E., Singer, T.P., 1991 Interaction of 1-methyl-4-phenylpyridinium ion (MPP+) and its analogs with the rotenone/piericidin binding site of NADH dehydrogenase. J. Neurochem. 56 , $1184-1190$

Richardson, J.R., Caudle, W.M., Guillot, T.S., Watson, J.L., Nakamaru-Ogiso, E., Seo, B.B., Sherer, T.B., Greenamyre, J.T., Yagi, T., Matsuno-Yagi, A., Miller, G.W., 2007. Obligatory role for complex I inhibition in the dopaminergic neurotoxicity of 1 methyl-4-phenyl-1,2,3,6-tetrahydropyridine (MPTP). Toxicol. Sci. 95, 196-204.

Saporito, M.S., Brown, E.M., Miller, M.S., Carswell, S., 1999. CEP-1347/KT-7515, an inhibitor of $c$-jun $\mathrm{N}$-terminal kinase activation, attenuates the 1-methyl-4-pheny tetrahydropyridine-mediated loss of nigrostriatal dopaminergic neurons in vivo. J. Pharmacol. Exp. Ther. 288, 421-427.

Singer, T.P., Ramsay, R.R., McKeown, K., Trevor, A., Castagnoli Jr, N.E., 1988. Mechanism of the neurotoxicity of 1-methyl-4-phenylpyridinium (MPP+), the toxic bioactivation product of 1-methyl-4-phenyl-1,2,3,6-tetrahydropyridine (MPTP). Toxicology 49, 17-23.

Sirinathsinghji, D.J., Heavens, R.P., McBride, C.S., 1988. Dopamine-releasing action of 1-methyl-4-phenyl-1,2,3,6-tetrahydropyridine (MPTP) and 1-methyl-4-phenylpyridine $(\mathrm{MPP}+)$ in the neostriatum of the rat as demonstrated in vivo by the push-pull perfusion technique: dependence on sodium but not calcium ions. Brain Res. 443, 101-116.

Sonsalla, P.K., Albers, D.S., Zeevalk, G.D., 1998. Role of glutamate in neurodegeneration of dopamine neurons in several animal models of parkinsonism. Amino Acids 14 69-74.

Staal, R.G., Sonsalla, P.K., 2000. Inhibition of brain vesicular monoamine transporter (VMAT2) enhances 1-methyl-4-phenylpyridinium neurotoxicity in vivo in rat striata. J. Pharmacol. Exp. Ther. 293, 336-342.

Staal, R.G., Hogan, K.A., Liang, C.L., German, D.C., Sonsalla, P.K., 2000. In vitro studies of striatal vesicles containing the vesicular monoamine transporter (VMAT2): ra versus mouse differences in sequestration of 1-methyl-4-phenylpyridinium. J. Pharmacol. Exp. Ther. 293, 329-335.

Stokes, A.H., Hastings, T.G., Vrana, K.E., 1999. Cytotoxic and genotoxic potential of dopamine. J. Neurosci. Res. 55, 659-665.

Sulzer, D., St Remy, C., Rayport, S., 1996. Reserpine inhibits amphetamine action in ventral midbrain culture. Mol. Pharmacol. 49, 338-342.

Thomas, B., Beal, M.F., 2007. Parkinson's disease. Hum. Mol. Genet. 16, R183-R194 Spec No. 2.

Vergo, S., Johansen, J.L., Leist, M., Lotharius, J., 2007. Vesicular monoamine transporter 2 regulates the sensitivity of rat dopaminergic neurons to disturbed cytosolic dopamine levels. Brain Res. 1185, 18-32.

Volbracht, C., van Beek, J., Zhu, C., Blomgren, K., Leist, M., 2006. Neuroprotective properties of memantine in different in vitro and in vivo models of excitotoxicity. Eur. J. Neurosci. 23, 2611-2622.

Wu, E.Y., Smith, M.T., Bellomo, G., Di Monte, D., 1990. Relationships between the mitochondrial transmembrane potential, ATP concentration, and cytotoxicity in isolated rat hepatocytes. Arch. Biochem. Biophys. 282, 358-362.

Wullner, U., Loschmann, P.A., Schulz, J.B., Schmid, A., Dringen, R., Eblen, F., Turski, L., Klockgether, T., 1996. Glutathione depletion potentiates MPTP and MPP+ toxicity in nigral dopaminergic neurones. Neuroreport 7, 921-923.

Zhou, C., Huang, Y., Przedborski, S., 2008. Oxidative stress in Parkinson's disease: a mechanism of pathogenic and therapeutic significance. Ann. N. Y. Acad. Sci. 1147 93-104.

Zhu, J.H., Horbinski, C., Guo, F., Watkins, S., Uchiyama, Y., Chu, C.T., 2007. Regulation of autophagy by extracellular signal-regulated protein kinases during 1-methyl-4phenylpyridinium-induced cell death. Am. J. Pathol. 170, 75-86. 